\title{
Molecular Imaging of Inflammatory Disease
}

\author{
Meredith A. Jones 1,2, William M. MacCuaig 1,2, Alex N. Frickenstein ${ }^{1,2}$, Seda Camalan ${ }^{3}$ (D), Metin N. Gurcan ${ }^{3}$, \\ Jennifer Holter-Chakrabarty ${ }^{2,4}$, Katherine T. Morris ${ }^{2,5}$ (D) Molly W. McNally ${ }^{2}$, Kristina K. Booth ${ }^{2,5}$, \\ Steven Carter ${ }^{2,5}$, William E. Grizzle ${ }^{6}$ and Lacey R. McNally ${ }^{2,5, *}$
}

1 Stephenson School of Biomedical Engineering, University of Oklahoma, Norman, OK 73019, USA; Meredith.jones@ou.edu (M.A.J.); bmaccuaig9@gmail.com (W.M.M.); africk256@ou.edu (A.N.F.)

2 Stephenson Cancer Center, University of Oklahoma, Oklahoma City, OK 73104, USA; jholter2@ouhsc.edu (J.H.-C.); katherine-morris@ouhsc.edu (K.T.M.); mwmcnally@hotmail.com (M.W.M.); Kristina-Booth@ouhsc.edu (K.K.B.); Steven-Carter@ouhsc.edu (S.C.)

3 Department of Internal Medicine, Wake Forest Baptist Health, Winston-Salem, NC 27157, USA; scamalan@wakehealth.edu (S.C.); mgurcan@wakehealth.edu (M.N.G.)

4 Department of Medicine, University of Oklahoma, Oklahoma City, OK 73104, USA

5 Department of Surgery, University of Oklahoma, Oklahoma City, OK 73104, USA

6 Department of Pathology, University of Alabama at Birmingham, Birmingham, AL 35294, USA; wgrizzle2@gmail.com

* Correspondence: lacey_mcnally@hotmail.com

check for updates

Citation: Jones, M.A.; MacCuaig, W.M.; Frickenstein, A.N.; Camalan, S.; Gurcan, M.N.; Holter-Chakrabarty, J.; Morris, K.T.; McNally, M.W.; Booth, K.K.; Carter, S.; et al. Molecular Imaging of Inflammatory Disease. Biomedicines 2021, 9, 152. https:// doi.org/10.3390/biomedicines9020152

Academic Editor: Moritz Wildgruber Received: 30 December 2020

Accepted: 31 January 2021

Published: 4 February 2021

Publisher's Note: MDPI stays neutral with regard to jurisdictional claims in published maps and institutional affiliations.

Copyright: (C) 2021 by the authors. Licensee MDPI, Basel, Switzerland. This article is an open access article distributed under the terms and conditions of the Creative Commons Attribution (CC BY) license (https:// creativecommons.org/licenses/by/ $4.0 /)$.
Abstract: Inflammatory diseases include a wide variety of highly prevalent conditions with high mortality rates in severe cases ranging from cardiovascular disease, to rheumatoid arthritis, to chronic obstructive pulmonary disease, to graft vs. host disease, to a number of gastrointestinal disorders. Many diseases that are not considered inflammatory per se are associated with varying levels of inflammation. Imaging of the immune system and inflammatory response is of interest as it can give insight into disease progression and severity. Clinical imaging technologies such as computed tomography $(\mathrm{CT})$ and magnetic resonance imaging (MRI) are traditionally limited to the visualization of anatomical information; then, the presence or absence of an inflammatory state must be inferred from the structural abnormalities. Improvement in available contrast agents has made it possible to obtain functional information as well as anatomical. In vivo imaging of inflammation ultimately facilitates an improved accuracy of diagnostics and monitoring of patients to allow for better patient care. Highly specific molecular imaging of inflammatory biomarkers allows for earlier diagnosis to prevent irreversible damage. Advancements in imaging instruments, targeted tracers, and contrast agents represent a rapidly growing area of preclinical research with the hopes of quick translation to the clinic.

Keywords: molecular imaging; inflammation; cardiovascular disease; rheumatoid arthritis; chronic obstructive pulmonary disease; graft vs. host disease; image analysis; machine learning

\section{Introduction}

Inflammation can manifest in all areas of the body and is often the common denominator between a plethora of diseases and infections. There is a current upsurge in preclinical and translation research to uncover the exact role that inflammation may have in disease progression to make a more accurate diagnosis. Much of this research focuses on imaging inflammation by targeting the immune system. When a pathogen elicits an immune response, there is an upregulation of immune cells such as macrophages, monocytes, and lymphocytes [1]. Monocytes and macrophages are recruited to the infection site where they proliferate and phagocytose the pathogen; it is through this phagocytotic mechanism that exogenous imaging agents can be internalized and the inflammatory response can be imaged [2]. Imaging of lymphocytes is mainly done through radiolabeled antibodies [3-6]. Molecular imaging of these cells allows for the non-invasive, in vivo visualization of these 
immune cells to characterize the extent and severity of the disease. Visualization of these immune cells as inflammatory biomarkers will have significant effects on the fields of personalized medicine and early diagnostics of inflammatory disease.

Molecular imaging relies on the presence of endogenous or exogenous contrast agents for the identification of inflamed tissue. While reliance on endogenous contrast is of interest due to decreased risk to patients, lack of specificity in regard to molecular processes limits the accuracy and application of such agents such as hemoglobin and deoxyhemoglobin $[7,8]$. As a result, molecular imaging has traditionally required tracer molecules specific for biological processes. These tracers consist of a contrast-generating agent, e.g., fluorescent dye, which is targeted for a molecule/function within the body. Such tracers offer high, controllable, and specific contrast, which is unachievable with endogenous contrast alone. Tracers have been utilized across many modalities; examples include radioactive atoms applied to sugars for metabolism tracking with positron emission tomography (PET)/SPECT [9], iodine-labeled tracers for X-ray-based imaging [10], and lanthanides that respond to an external magnetic field for MRI [11]. However, further development of small molecule tracers has slowed significantly due to toxicity concerns and poor sensitivity as a result of weak signal specificity and rapid bodily clearance [1]. The utilization of nanoparticles is a potentially viable method to add exogenous contrast for the purpose of molecular imaging in efforts to overcome limitations that often plague fluorescent probes. While many types of nanoparticles have shown potential, nanoparticles consistently miss expectations in a clinical setting, owing to poor target specificity. Recent advancements in active targeting have improved such outlooks [12]. Approaches to functionalize nanoparticles provide increased specificity through targeting extracellular receptors or key features of the target environment. Identification and exploitation of the molecular signature of diseases allows for the development of novel imaging probes to reveal pathological information about the tissue without the need for invasive biopsies.

Standard clinical imaging techniques such as computed tomography (CT), magnetic resonance imaging (MRI), and ultrasound (US) are traditionally used to reveal anatomical information, providing information required for diagnosis but do not yield molecular information that could be critical for identifying appropriate treatments. For example, the monitoring of response of tumors to therapy uses the Response Evaluation Criteria in Solid Tumors (RECIST) score, which is reliant on changes in tumor size [13]. It may take multiple weeks for a measurable change in tumor size to be observed; however, molecular changes will precede anatomical changes. Recent advancements in contrast agents allows for the extraction of functional and molecular information as well as anatomical information from standard imaging modalities.

The choice of contrast agent for MRI is dependent on the objective of the imaging session. T1-weighted MRI involves the injection of a paramagnetic metal agent, often gadolinium based, which shortens the T1 relaxation time resulting in an enhanced signal [14]. The low sensitivity and limited specificity of gadolinium-based contrast agents renders T1-weighted MRI suboptimal for molecular imaging [15]. T2-weighted MRI most often involves the injection of superparamagnetic iron oxide nanoparticles (SPIONs), resulting in negative contrast enhancement. SPIONs usually range in size from 10 to $100 \mathrm{~nm}$ and are often dextran-coated to increase biocompatibility $[16,17]$. The uptake of SPIONs by active macrophages at sites of inflammation make T2-weighted MRI an appropriate choice for molecular imaging of inflammation $[16,18]$. MR spectroscopy is another MR technique that acquires the molecular spectra of the tissue of interest in order to reveal information about the concentration and presence of different metabolites in the tissue [19]. While MR spectroscopy provides more information than standard MRI, it is limited by poor spatial resolution and low sensitivity, since the agents of interest exist in very low concentrations [20]. Chemical exchange saturation transfer (CEST) MR imaging involves the exchange of magnetization from the target agent to the surrounding water molecules so that the signal reduction through the saturation effect is seen only on the water molecules and not on the target agent. CEST imaging is dependent on the chemical composition of 
the target metabolite and the radiofrequency pulse that initiates the chemical exchange of the proton [20]. Then, the sensitivity of CEST imaging is directly related to the chemical exchange rate of the proton transfer, allowing for molecular imaging of specific metabolites that are found at low concentrations [21]. While the majority of research investigating CEST agents is primarily focused on oncology [22], there has been preclinical work investigating the role of CEST imaging and MR spectroscopy in neuroinflammation [23-25].

As inflammation is a hallmark of many diseases, the ability to image inflammatory biomarkers on the molecular level will allow for better understanding of disease pathophysiology and ultimately better patient care. The purpose of this review is to highlight the existing molecular imaging techniques used to assess the inflammatory state of cardiovascular disease, rheumatoid arthritis, chronic obstructive lung disease, and gastrointestinal disorders.

\section{Imaging Inflammatory Disease}

\subsection{Cardiovascular Disease (CVD)}

Cardiovascular disease (CVD) is the leading cause of death worldwide [26,27]. CVD is a broad term that encompasses many heart and circulatory system conditions, most of which develop gradually and are only diagnosed after the presentation of symptoms, which often result in fatality, mainly heart attack or stroke [28]. One person will die every $36 \mathrm{~s}$ from CVD in the United States alone, and with an increase in the number of smokers and growing obesity rates - two major risk factors for developing CVD-it is now more important than ever to focus on the development of early screening tools to identify the markers of CVD before it is too late [29-31].

Atherosclerosis occurs when plaque builds up inside the artery; over time, this plaque will harden and the artery will narrow, limiting blood flow, which often results in cardiovascular disease [32]. This plaque buildup is often only detected at the onset of symptoms, such as myocardial infarction or stroke, which are two of the most common causes of mortality in the United States and Europe [31]. At present, catheter-based X-ray angiography or intravascular ultrasound is used to identify coronary atherosclerosis, but this procedure is extremely invasive and only yields anatomical information about the degree of stenosis $[26,33,34]$. Non-invasive molecular imaging techniques must be utilized to characterize the plaque activity to determine which patients are extremely high-risk and require immediate intervention. Coronary CT angiography (CCTA) is a method for identifying the degree of stenosis and the plaque composition [35]. CCTA is able to score the degree of calcification of the coronary plaque, which is a strong predictor of a serious cardiovascular event [36,37]. While CCTA does provide functional information about CVD, it falls short of being a true molecular imaging technique, as it does not visualize changes on molecular level.

An increase in macrophage activity, reflective of inflammation, has been linked to a higher risk of plaque rupture; therefore, molecular imaging of macrophage activity in the arteries can help identify areas where plaque may be building [38-40]. ${ }^{18} \mathrm{~F}$-Flourodeoxyglucose (FDG) PET imaging is commonly used to image the inflammatory component of atherosclerosis [41-44]. ${ }^{18} \mathrm{~F}-\mathrm{FDG}$ is a radiolabeled glucose molecule, which is internalized by cells through the same mechanism in which glucose is metabolized. Both ${ }^{18} \mathrm{~F}-\mathrm{FDG}$ and glucose are phosphorylated by hexokinase, where ${ }^{18}$ F-FDG becomes ${ }^{18}$ F-FDG-6-phosphate and glucose become glucose-6-phosphate. ${ }^{18}$ F-FDG-6-phosphate cannot be further metabolized by glucose-6-phosphate isomerase; therefore, it remains inside the cell for PET imaging [45]. In atherosclerosis, the accumulation of macrophages at locations of active plaque buildup requires a large amount of glucose, thus causing the upregulation of glucose transporters on the surface of these macrophages. Therefore, increased ${ }^{18}$ F-FDG uptake will be seen at locations of increased macrophage density, which is reflective of inflammation and active plaque buildup (Figure 1) $[38,46]$. It is unknown what the influence of ${ }^{18}$ F-FDG uptake from other cells, such as, neutrophils, endothelial cells, and lymphocytes, has on the observed signal $[33,40]$. Once the plaque cells have calcified, ${ }^{18}$ F-FDG uptake will subside substantially, making this type of PET imaging ineffective. PET imaging of atherosclerosis using ${ }^{18}$ F-FDG requires a circulation time of $2-3 \mathrm{~h}$ to allow for accumulation in the arterial wall 
and the decay or excretion of background levels of ${ }^{18}$ F-FDG [40]. ${ }^{18}$ F-FDG PET imaging in oncology typically needs $1 \mathrm{~h}$ of circulation time before imaging can begin.

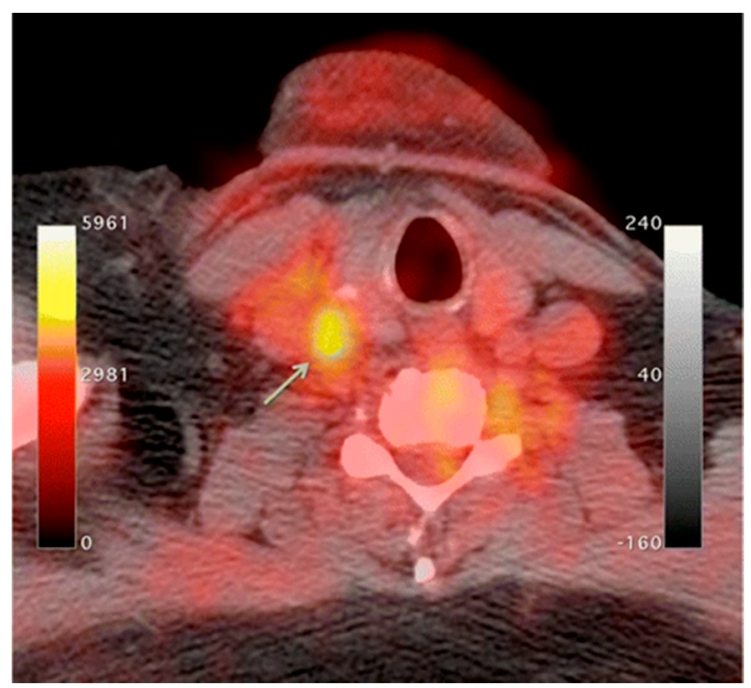

Figure 1. ${ }^{18}$ F-Flourodeoxyglucose $\left({ }^{18} \mathrm{~F}-\mathrm{FDG}\right)$ positron emission tomography (PET)/computed tomography (CT) imaging of activated macrophages to visualize vulnerable plaques through increase in glucose metabolism. Higher ${ }^{18}$ F-FDG update is seen in the right common carotid artery (arrow) [47].

${ }^{18} \mathrm{~F}$-FDG PET imaging is non-specific; therefore, it is complicated by highly metabolic neighboring tissues such as myocardial cells and neurons $[38,47,48]$. The suppression of myocardial ${ }^{18}$ F-FDG uptake can be achieved through dietary manipulation (high-fat, low-carb) to shift the body into beta-oxidation of fatty acids instead of metabolizing glucose as a primary energy source to try and limit this background activity $[49,50]$. Other radiotracers can be utilized that are specific to macrophages, limiting the effects from other highly metabolic cells. Translocator protein (TSPO)/peripheral benzodiazepine (PBR) receptors are overexpressed in activated macrophages, which is a great option for active targeting [51]. ${ }^{11} \mathrm{C}-\mathrm{PK} 11195,(1-(2-C h l o r o p h e n y l)-N-(11 C) m e t h y l-N-(1-m e t h y l p r o p y l)-$ 3 -isoquinoline carboxamide) is a radiolabeled TSPO ligand that has been used as a PET tracer to visualize inflammatory plaque in atherosclerosis [51-54]. ${ }^{11} \mathrm{C}-\mathrm{PK} 11195$ uptake in patients with atherosclerosis was higher in patients who had a myocardial infarction or stroke compared to patients who were asymptomatic [53]. Other radiolabeled TSPO targeted ligands include ${ }^{18} \mathrm{~F}-\mathrm{GE}-180$, which showed a better signal-to-noise ratio and lower non-specific binding; more work must be done to validate this radiotracer [55].

${ }^{68} \mathrm{Ga}$-DOTATATE is another radiolabeled tracer that can be used to target inflammatory plaque in atherosclerosis by targeting the somatostatin receptor subtype 2 (SSR-2), which is also overexpressed on activated macrophages [56,57]. A copper radiolabel $\left({ }^{64} \mathrm{Cu}\right)$ is frequently substituted for gallium because of the longer half-life and shorter positron range, which allow for better spatial resolution $[47,58]$. CXC-motif chemokine receptor 4 (CXCR-4) is also overexpressed on many immune cells, particularly monocytes and macrophages, making this receptor a good target for imaging inflammatory plaques of atherosclerosis [59]. Radiolabeled pentixafor, ${ }^{68} \mathrm{Ga}$-pentixafor, targets this CXCR-4 receptor for the quantification of arterial inflammation in atherosclerotic plaques [59-61].

As plaque builds up inside the artery, macrophages become active, and the region often becomes hypoxic due to the reduced oxygen diffusion efficiency from the thickening of the vessel wall. As active macrophages reflect sites of inflammation, it is suspected that macrophage activity is partially mediated by hypoxia as atherosclerotic plaques overexpress hypoxia-inducible factor 1-alpha (HIF-1 $\alpha)[33,47,62]$. There is ongoing research that focuses on the imaging of hypoxia as a surrogate biomarker of plaque inflammation and atherosclerosis. Radiolabeled ligands such as ${ }^{18} \mathrm{~F}$-fluoromisonidazole (FMISO) or 
${ }^{18}$ F-EF5 have been used to detect atherosclerotic plaques through PET imaging of hypoxia preclinically; more work must be done to advance these findings to the clinic [63-65].

\subsection{Rheumatoid Arthritis}

Rheumatoid arthritis (RA) is an autoimmune disorder that is characterized by chronic inflammation of the joints often causing degradation of the cartilage and bone, leading to a diminished quality of life due to musculoskeletal deficits and chronic pain [66]. For every 1000 adults, five will have RA, making it one of the most prevalent chronic inflammatory conditions worldwide [67]. RA etiology is not exactly known due to the synergistic effects of epigenetics [68] and environmental factors (smoking [69,70], obesity [71-73], and alcohol consumption [74-76]). Autoantibodies such as antibodies to citrullinated protein antigens (ACPAs) or rheumatoid factor (RF) have well-established roles in RA as accurate predictors of disease severity [77-79]. The current standard of care for the diagnosis of RA is through blood work to monitor the erythrocyte sedimentation rate (ESR), C-reactive protein levels (CRP), RF, and ACPAs $[77,80]$ or anatomical imaging through MRI and ultrasound [81]. Power Doppler ultrasound (PDUS) is an US technique that is commonly used in the evaluation of RA, as it can visualize blood flow as well as anatomical information. The locations of active inflammation will have increased blood flow, making PDUS a good choice for not only diagnosing RA but also for assessing the severity and response to treatment $[82,83]$.

Synovial membrane inflammation (synovitis) is a key characteristic of RA that involves the upregulation of both innate and adaptive immune cells and fibroblast-like synoviocytes (FLS) [84]. This immune response coupled with FLS results in inflammation and the activation of osteoclasts that leads to the degradation of cartilage $[85,86]$. The synovial fluid contains a variety of activated macrophages, B cells, and T cells, all of which are good targets for the molecular imaging of RA. The overexpression of inflammatory biomarkers can damage the existing vasculature, resulting in the enhanced permeability and retention (EPR) effect [87]. The newly permeable environment allows for the passive targeting of the immune cells of an inflammatory response. SPION-based contrast agents are small enough to penetrate the synovial fluid where they are phagocytized by active macrophages and can be visualized by T2-weighted MRI $[18,88,89]$.

Activated macrophages can also be imaged using ${ }^{18} \mathrm{~F}-\mathrm{FDG}$ PET imaging in the same manner described above [90-92]. While ${ }^{18}$ F-FDG PET imaging targets activated macrophages through elevated levels of glucose metabolism, there are more specific methods used to image active macrophages in RA. Folate receptor $\beta(\mathrm{FR} \beta)$, a glycosylphosphatidyl plasma membrane anchored protein used to internalize folate needed for DNA synthesis and cell division, is overexpressed on activated macrophages in the synovial fluid, making it an attractive target for the molecular imaging of RA [93,94]. Radiolabeled folic acid can be imaged through scintigraphy or PET imaging for the detection of inflammation in the joints (Table 1) [93,95-97]. Spatial resolution of PET images is poor; a fluorescently labeled folate probe (NIR2-folate) can be visualized with NIR fluorescence imaging with greater spatial resolution, but this technique is limited by penetration depth due to light scattering in tissue [98]. Many other methods exist for targeting activated macrophages in RA [99].

Due to the abundance of immune cells in the synovial fluid, there is an overexpression of inflammatory cytokines that elicit certain cellular responses that can then be targeted for imaging. The presence of interleukin- 1 and tumor necrosis factor alpha (TNF- $\alpha$ ) stimulate the transient expression of surface protein E-selectin on vascular endothelial cells and the overexpression of matrix metalloproteases (MMPs) in the synovial fluid. Anti E-selectin antibodies and MMP-targeted probes can be either radiolabeled or conjugated to an NIR dye and visualized through scintillation/PET or NIR fluorescence imaging [100-104]. Biologicals used as therapeutics for RA can also be radiolabeled and used to image RA. Rituximab, a monoclonal antibody that targets CD20, a cell surface marker that is expressed on most $\mathrm{B}$ cells, can be radiolabeled and used as a probe for the in vivo molecular imaging 
of RA based on B lymphocyte accumulation in the synovial fluid (Figure 2) $[4,105,106]$. Infliximab, a monoclonal antibody that targets tumor necrosis factor alpha (TNF $\alpha$ ), has also been radiolabeled with ${ }^{99 \mathrm{~m}} \mathrm{Tc}$, which demonstrated a superior sensitivity to inflammation than MRI and clinical examinations in patients with RA [107-109].

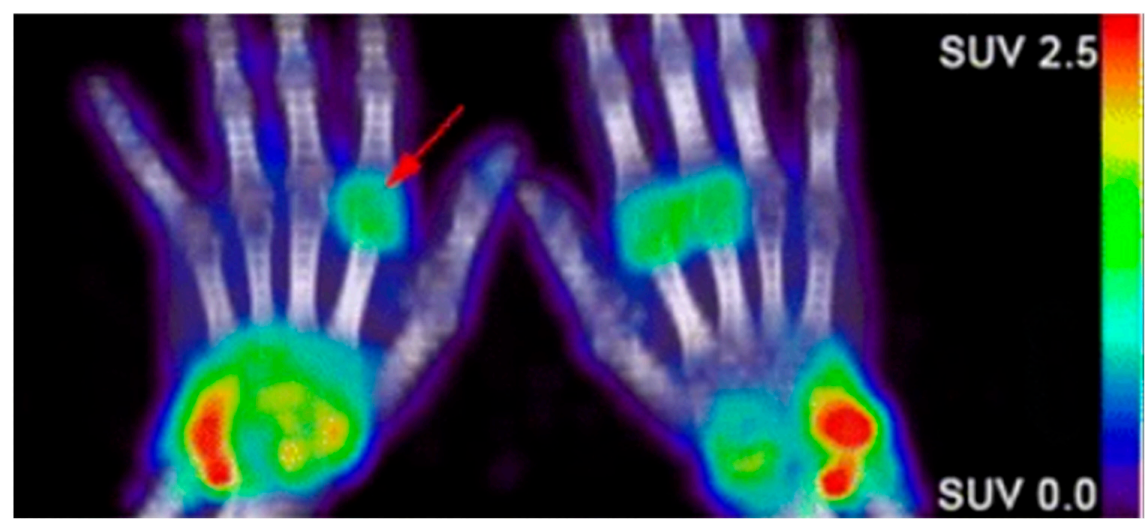

Figure 2. Confirmation of rheumatoid arthritis (RA) in the wrists/hands of patients using ${ }^{89} \mathrm{Zr}$ rituximab PET imaging to target B-cell accumulation [105].

Carbohydrate-binding proteins, L-selection and P-selection, are involved in the movement of immune cells before and during the inflammatory response [110]. Polyanionic dendritic polyglycerol sulfate (dPGS) targets inflammation through binding with these selectins. Conjugation with indocyanine green (ICG), an NIR fluorescent dye, allowed for the in vivo differentiation of RA-positive joints from RA negative joints in a preclinical rat arthritis model as seen by a 3.5-fold greater fluorescence imaging signal [111]. As the clinical translation of NIR fluorescence is limited by low penetration depth, multispectral optoacoustic tomography (MSOT) can overcome those limitations. MSOT imaging is based on a light-in, sound-out approach, having all the benefits of optical imaging but allowing for increased depth penetration, since photon scattering is irrelevant to acoustic waves [112] Then, NIR-labeled dPGS can be imaged at much greater depths using MSOT [113].

\subsection{Chronic Obstructive Pulmonary Disease (COPD)}

Chronic obstructive pulmonary disease (COPD) is a preventable, but underdiagnosed inflammatory disease with an extremely high morbidity and mortality rate [114]. Approximately $90 \%$ of all COPD cases are related to smoking, yet only $20 \%$ of smokers will develop COPD, suggesting that other environmental and genetic factors must also play a role $[115,116]$. COPD is characterized by airway obstruction due to chronic inflammation and tissue damage caused by a decrease in alveolar elasticity and gas exchange, which ultimately leads to an irreversible decrease in lung function [117]. Pulmonary function testing (PFT) to measure airflow coupled with conventional imaging modalities, CT or MRI, to visualize morphological changes in the airway, is the current standard for diagnosing COPD [118]. Since COPD is an inflammatory disease, these imaging modalities must infer about the inflammatory state through surrogate biomarkers such as airway thickness and airway wall area [117]. Emphysema and chronic bronchitis are two subtypes of COPD that have very distinct molecular characteristics. Emphysema is an irreversible condition induced by smoking or inhaling irritants that destroys the alveoli; this leads to a decrease in the surface area of the lungs, making it difficult to obtain oxygen, causing inflammation of the lung parenchyma $[119,120]$. Chronic bronchitis is the persistent inflammation of the bronchial tubes due to a chronic cough, which leads to sputum build up in the airways, restricting airflow [121,122]. Early identification of COPD and proper differentiation of different phenotypes is imperative for the development of a proper treatment plan.

Molecular imaging techniques have been developed to target the inflammatory response of COPD. As the airways become inflamed, there will be changes in the pulmonary blood flow as well as airflow. These changes often precede morphological changes that can 
be detected by CT. Perfusion scintigraphy through the injection of ${ }^{99 m}$ Tc-labeled macroaggregated albumin coupled with ventilation scintigraphy through the inhalation of either an inert radioactive gas $\left({ }^{81 \mathrm{~m}} \mathrm{Kr}\right.$ or $\left.{ }^{133} \mathrm{Xe}\right)$, an aerosol-based ${ }^{99 \mathrm{~m}} \mathrm{Tc}$-labeled DTPA, or Technegas $\left({ }^{99 \mathrm{~m}}\right.$ Tc-labeled carbon particles) will uncover aspects of the heterogeneity of the disease that cannot be seen using PFT or CT [123]. A great comparative study of these radiolabeled tracers in ventilation scintigraphy is found here [124]. The Ventilation to Perfusion (V/Q) ratio obtained will yield important information about regional differences in airflow and inflammation, where larger $\mathrm{V} / \mathrm{Q}$ values indicate emphysema and lower values reflect chronic bronchitis [125,126]. Similarly, MRI using hyperpolarized noble gas $\left({ }^{3} \mathrm{He}\right.$ or $\left.{ }^{129} \mathrm{Xe}\right)$ can also be used to assess the ventilation status through imaging of the airspaces of the lungs rather than the tissue [127]. Apparent diffusion coefficient (ADC) maps of the hyperpolarized gas can be obtained on a voxel-wise basis using diffusion-weighted MRI (DWI-MRI), where high ADC values reflect areas of severe disease $[128,129]$. While hyperpolarized MRI is able to visualize the ventilation deficiencies associated with COPD, it is limited by spatial resolution and the ability of the patient to hold their breath.

As with other inflammatory diseases, COPD can also be visualized through immune cells. ${ }^{18}$ F-FDG PET/CT imaging is commonly used to monitor the metabolic activity of immune cells to diagnose and identify disease severity [130-133]. Since ${ }^{18}$ F-FDG is a nonspecific biomarker of immune activity, the addition of ${ }^{11}$ C-PK11195, a macrophage-targeted radiotracer, allows for the non-specific visualization of neutrophil activity as well as the more specific visualization of macrophage accumulation. A study involving six patients with COPD and five control subjects saw a greater accumulation of ${ }^{18} \mathrm{~F}-\mathrm{FDG}$ in all COPD patients compared to control, and greater ${ }^{11}$ C-PK11195 accumulation in four of six COPD patients compared to control [134]. Macrophages will secrete matrix metalloproteases (MMPs) and many other cytokines, which are all attractive options for the molecular imaging of COPD. Using a mouse model of COPD, a radiofluorinated probe, ${ }^{18} \mathrm{~F}-\mathrm{IPFP}$, was developed and tested to target MMP-9 and MMP-12; the accumulation of ${ }^{18} \mathrm{~F}-\mathrm{IPFP}$ was $4 \times$ higher in the lungs of COPD mice than in normal mice [135]. ${ }^{99 m}$ Tc-labeled RP805 is another MMP targeted radiotracer that saw significantly greater accumulation in IL-13 transgenic mice than control mice using SPECT/CT (Figure 3) [136].
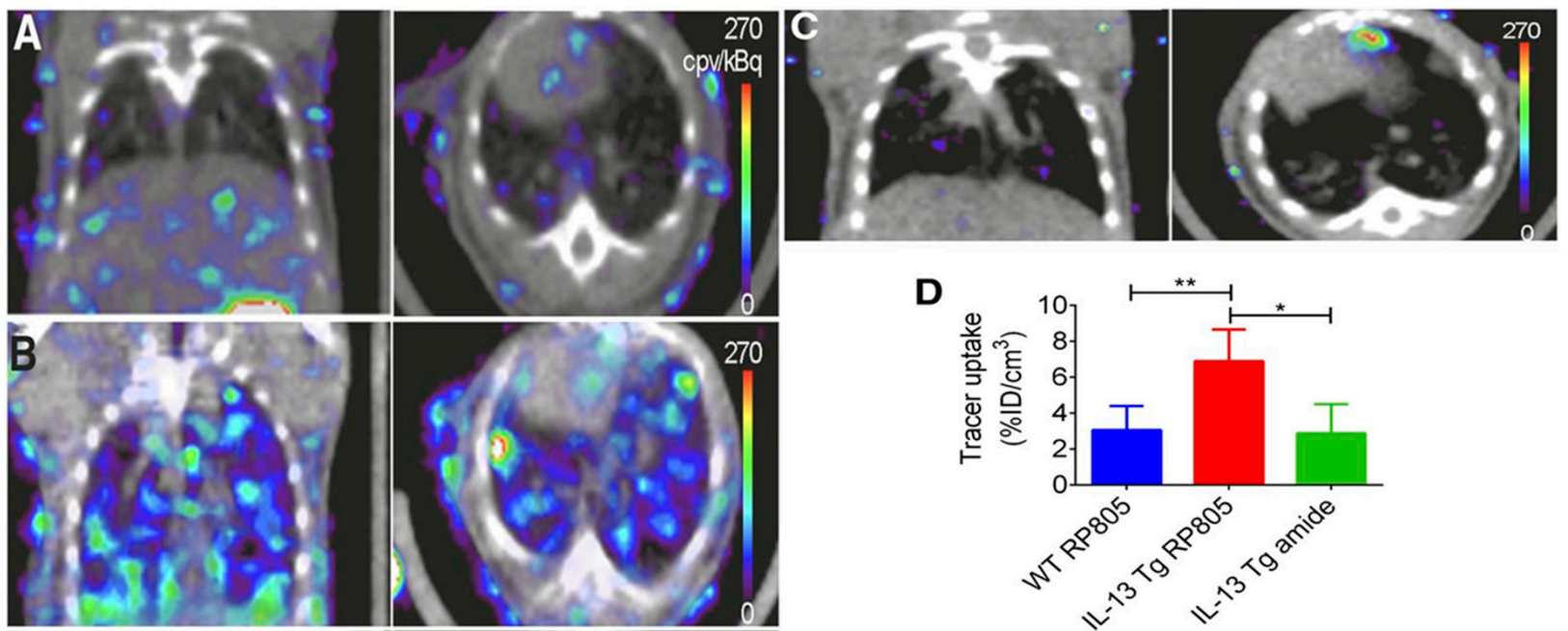

Figure 3. Coronal (left) and transversal (right) SPECT/CT imaging of matrix metalloproteases (MMPs). (A) Wild-type mice injected with ${ }^{99} \mathrm{~m}$ Tc-labeled RP805 (B) IL-13 transgenic mice injected with ${ }^{99 m}$ Tc-labeled RP805 (C) IL-13 transgenic mice injected with an amide analog tracer as a control. (D) Quantification of uptake in SPECT images. ${ }^{*} p<0.01{ }^{* *} p<0.001$ [136].

\subsection{Gastrointestinal}

Different gastrointestinal (GI) diseases can present with common, non-specific symptoms such as diarrhea and abdominal pain, making accurate diagnosis challenging without molecular information in addition to history and physical exam. $[137,138]$. Globally, the 
prevalence of inflammatory GI conditions such as inflammatory bowel disease (IBD) has increased significantly over time [139], particularly in developing countries [140]. Several causes, including genetic factors, diet, and infection, can result in inflammation of the GI tract. Identification of GI inflammation can aid in monitoring response to interventions. Subsequently, appropriate treatment can be administered to relieve symptoms or prevent disease progression. This can be especially critical in lowering patient risk for colorectal cancers [141].

Historically, tests using blood, stool, or biopsied tissue samples have been paired with invasive imaging techniques, such as endoscopy, to diagnose and assess patient GI disease [141]. Currently available invasive and non-invasive imaging techniques such as endoscopy, CT, MRI, and US, can show the macroscopic structural abnormalities associated with inflammatory bowel disease such as bowel wall thickening, abscesses, or fistulas to identify the scope of disease [142]. When combining multiple standard imaging modalities, the presence of inter-clinician reader variability and the lack of molecular information contained in the images (Figure 4) often requires a biopsy for an accurate diagnosis. In the context of Figure 4, the numerous lesions within the colon result in a higher potential of a biopsy sampling error and the possibility to miss areas of early-stage colon cancer.
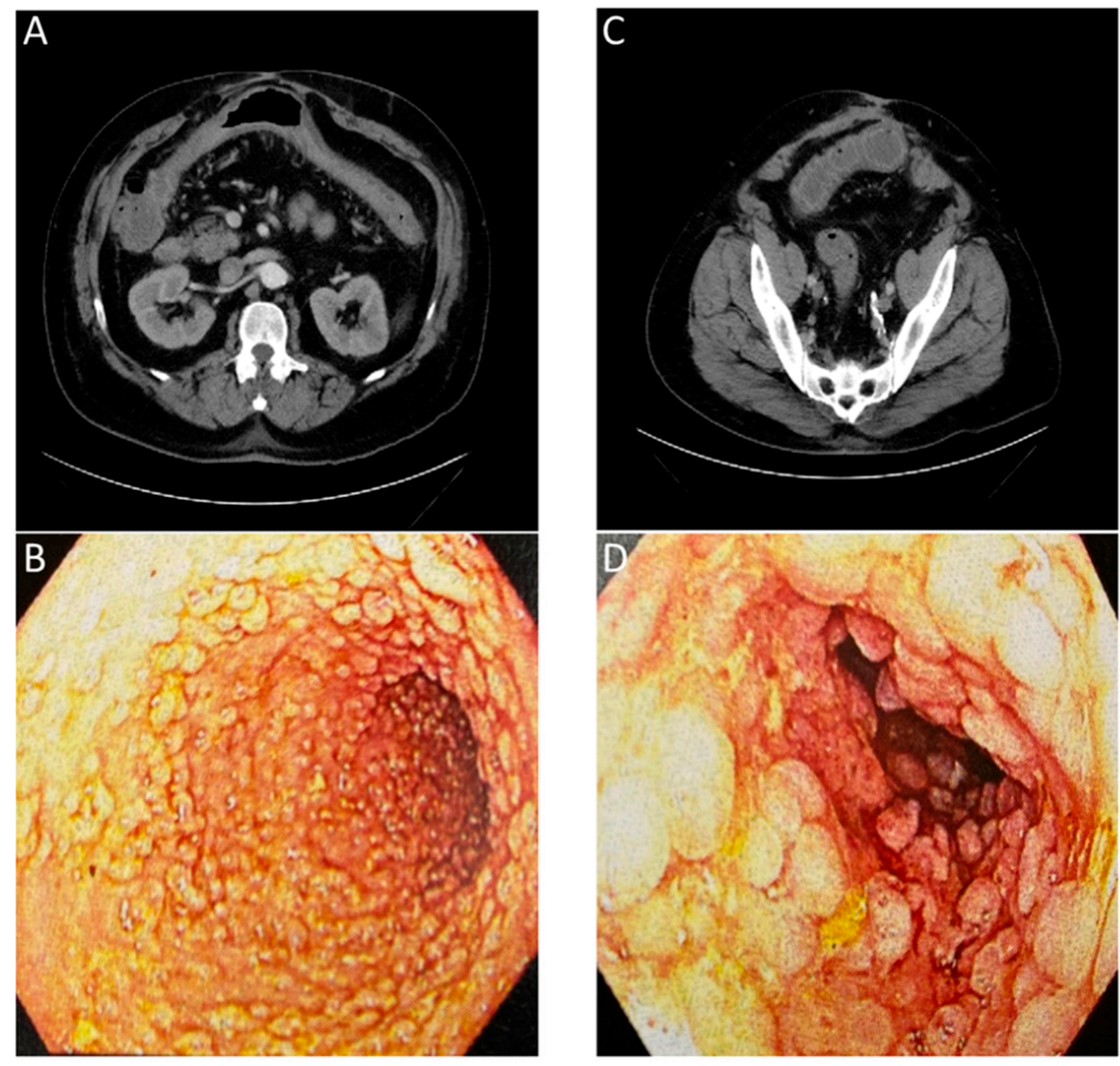

Figure 4. Images of a patient with history of chronic diarrhea that is occasionally bloody. CT ordered for unrelated reasons incidentally showed non-specific inflammation. Correlation with endoscopy showed substantial chronic inflammation. (A) CT with arrows showing inflammation of transverse colon. (B) Endoscopic images of transverse colon with diffuse pseudopolyps. (C) CT with arrows showing inflammation of sigmoid colon. (D) Endoscopic images of sigmoid colon with diffuse pseudopolyps. The lack of an inflammation or cancer specific contrast agent for the CT or endoscopic evaluation required a biopsy to confirm a lack of neoplasia. 
PET imaging is currently the only clinically approved molecular imaging approach for GI inflammation $[143,144]$. Specifically, ${ }^{18}$ F-FDG PET is used to measure the extent and magnitude of GI inflammation, indicating areas of low or high inflammation based on metabolic differences throughout the GI tract. The high metabolic need of inflamed tissue alongside the increased presence and activity of immune cells, such as leukocytes, results in increased glucose metabolism at sites of inflammation [145]. Differences in ${ }^{18}$ F-FDG consumption highlight areas of increased inflammation while contrasting against normal healthy tissue. PET alone offers limited spatial resolution despite its potential for high contrast imaging. Additionally, the uptake of ${ }^{18}$ F-FDG occurs in off-target sites, resulting in high background signal. As such, PET is frequently paired with either CT or MRI imaging to better monitor disease status and accurately assess disease location, as shown in (Figure 5) [146-148].
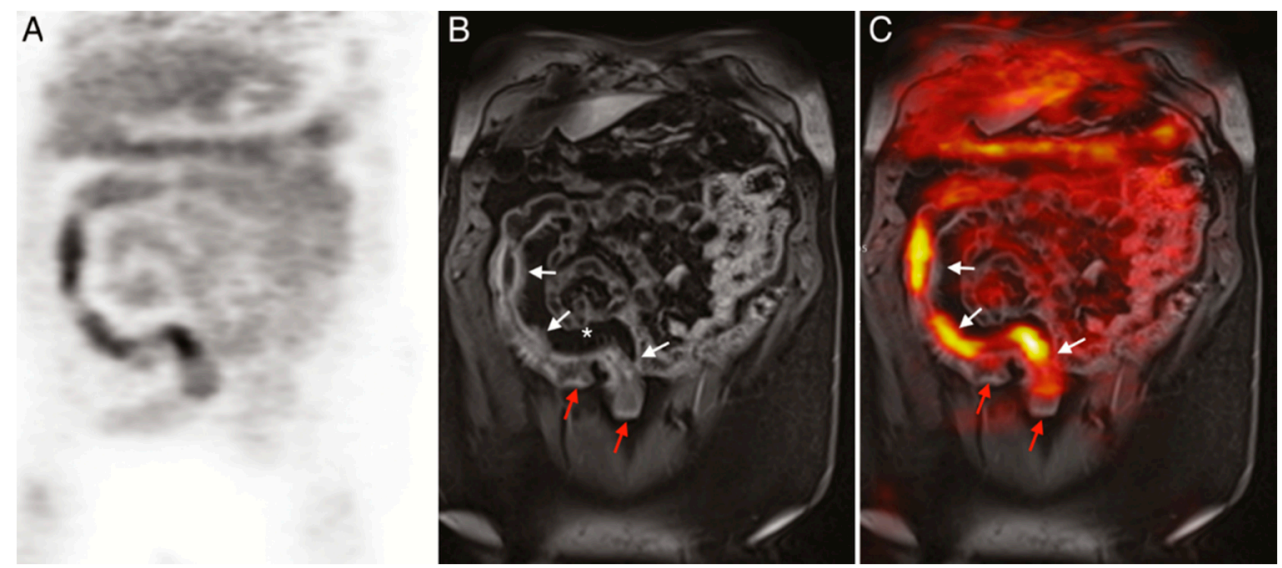

Figure 5. (A) ${ }^{18}$ F-FDG PET image of human patient with Crohn's disease. (B) T1-weighted magnetic resonance imaging (MRI) image of the same patient. (C) Merged PET/MRI. White arrows indicate locations of acute inflammation while red arrows highlight damage resulting from earlier disease action. The asterisk $\left(^{*}\right)$ shows a site of proliferation of fibrofatty compounds in the mesentery. SUVmax of ${ }^{18}$ F-FDG 5.6-9.2 vs. SUVmax of background bowel 1.5-2.8 [147].

Current molecular imaging techniques prove mostly effective for verifying the extent and magnitude of GI inflammation. Preclinically, there has been investigation into the manipulation of contrast agents for the molecular imaging of GI inflammation. Wang et al. quantified inflammation in acute colitis mouse models using ultrasound with a P- and E-selectin targeted contrast agent and ${ }^{18}$ F-FDG-PET/CT. Similar results were obtained with both modalities [149]. P- and E-selectin are overexpressed on endothelial cells at sites of active inflammation, suggesting the future utility of this work in inflammatory GI disorders. While not practiced in the clinic at this time, immuno-PET techniques use radiolabeled proteins to target the upregulated immune cell presence or biochemical activity around inflamed tissues [150,151]. For example, antibody fragments targeting mouse CD4 cells, which are increasingly present at sites of GI inflammation, indicated the location and intensity of colorectal inflammation in mouse models [152]. Another modality undergoing preclinical assessment for the imaging of inflammation is multispectral optoacoustic tomography (MSOT). MSOT permits accurate, non-invasive imaging of the molecular characteristics of the disease through the visualization of exogenous or endogenous contrast agents $[153,154]$. Preclinical MSOT analysis has been shown to accurately detect in vivo colitis through measuring hypervascularity, which is common in inflamed tissue, and oxyhemoglobin levels in inoculated mouse models [155]. Alongside imaging modalities, new molecular targets are being investigated for improved diagnostic capabilities. $\alpha_{4} \beta_{7}$ integrin is currently under investigation to determine whether it has the potential to increase the accuracy of IBD imaging. This is based on the increased presence of $\alpha_{4} \beta_{7}$ integrin on the activated lymphocytes found in inflamed tissue $[156,157]$. Endothelial growth factor receptor (EGFR) may be another target for imaging given its overexpression in inflamed and 
malignant cells. One study demonstrated the ability of radiolabeled anti-EGFR antibody fragments to successfully detect sites of IBD in mouse models, presenting greater target specificity and signal intensity relative to ${ }^{18}$ F-FDG [158]. As new markers, probes, and imaging modalities are developed or found, accuracy in imaging diagnoses and tracking of GI inflammation is sure to improve.

Table 1. Summary of the molecular targets and tracers used to identify inflammatory disease that are discussed in this review.

\begin{tabular}{|c|c|c|c|c|}
\hline Disease & Target & Tracer & Inflammatory Component & Source \\
\hline \multirow{6}{*}{$\begin{array}{l}\text { Cardiovascular } \\
\text { Disease }\end{array}$} & Glucose Metabolism & ${ }^{18}$ F-Flourodeoxyglucose (FDG) & Activated macrophage accumulation & [41-44] \\
\hline & $\begin{array}{l}\text { Translocator protein } \\
\text { (TSPO) receptors }\end{array}$ & $\begin{array}{l}{ }^{11} \mathrm{C}-\mathrm{PK} 11195 \\
{ }^{18} \mathrm{~F}-\mathrm{GE}-180\end{array}$ & Overexpressed on activated macrophages & [51-54] \\
\hline & $\begin{array}{l}\text { Somatostatin receptor } \\
\text { subtype-2 (SSR-2) }\end{array}$ & $\begin{array}{l}{ }^{68} \mathrm{Ga}-\mathrm{DOTATATE} / \\
{ }^{64} \mathrm{Cu} \text {-DOTATATE }\end{array}$ & Overexpressed on activated macrophages & {$[56,57]$} \\
\hline & Chemokine receptor 4 & ${ }^{68}$ Ga-pentixafor & Overexpressed on activated macrophages & [59-61] \\
\hline & \multirow{2}{*}{ Hypoxia } & ${ }^{18} \mathrm{~F}$-fluoromisonidazole (FMISO & \multirow{2}{*}{$\begin{array}{l}\text { Activated macrophage accumulation } \rightarrow \\
\text { inflammation and thickening of the vessel wall } \rightarrow \\
\text { decreased oxygen diffusion efficiency } \rightarrow \text { Hypoxia }\end{array}$} & [64] \\
\hline & & ${ }^{18}$ F-EF5 & & {$[65]$} \\
\hline \multirow{11}{*}{$\begin{array}{l}\text { Rheumatoid } \\
\text { Arthritis }\end{array}$} & Glucose metabolism & ${ }^{18}$ F-Flourodeoxyglucose (FDG) & Activated macrophage accumulation & [90-92] \\
\hline & \multirow[t]{2}{*}{ Folate receptor $\beta(\mathrm{FR} \beta)$} & $\begin{array}{l}{ }^{18} \text { F-Fluoro-PEG-folate } \\
{ }^{111} \text { In-folate conjugate }\end{array}$ & \multirow{2}{*}{$\begin{array}{l}\text { Overexpressed on activated macrophages within the } \\
\text { synovial fluid }\end{array}$} & [93,95-97] \\
\hline & & NIR2-Folate & & [98] \\
\hline & \multirow{3}{*}{ E-selectin } & ${ }^{111}$ In-labeled anti-E-selectin MAb & \multirow{3}{*}{ Overexpressed on endothelial cells due to TNF $\alpha$} & [100] \\
\hline & & $\begin{array}{l}\text { DyLight 750/anti-E-selectin } \\
\text { Mab probe }\end{array}$ & & [87] \\
\hline & & ${ }^{99 m}$ Tc-labelled anti-E-selectin FAb & & [102] \\
\hline & \multirow[b]{2}{*}{ MMPs } & ${ }^{18}$ F-pyriminde-2,4,6,-triones & \multirow{2}{*}{$\begin{array}{l}\text { Elevated levels in synovial fluid correlate with } \\
\text { inflammatory response }\end{array}$} & [104] \\
\hline & & $\begin{array}{l}\text { NIR fluorescent MMP-3 specific } \\
\text { chitosan nanoparticle }\end{array}$ & & [103] \\
\hline & CD20 & $\begin{array}{r}{ }^{124} \mathrm{I} \text {-Rituximab } \\
{ }^{89} \mathrm{Zr} \text {-Rituximab }\end{array}$ & $\begin{array}{l}\text { Overexpressed on B lymphocytes as they accumulate } \\
\text { in synovial fluid }\end{array}$ & {$[105,106]$} \\
\hline & $\mathrm{TNF} \alpha$ & ${ }^{99 m}$ Tc-Infliximab & Overexpressed in synovial fluid & {$[107,109]$} \\
\hline & L-selectin/P-selectin & $\begin{array}{l}\text { NIR Fluorescent Polyanionic } \\
\text { dendritic polyglycerol } \\
\text { sulfate (dPGS) }\end{array}$ & $\begin{array}{l}\text { Movement of immune cells to the } \\
\text { inflammatory location }\end{array}$ & {$[111,113]$} \\
\hline \multirow{6}{*}{ COPD } & Pulmonary perfusion & $\begin{array}{l}{ }^{99 \mathrm{~m}} \mathrm{Tc}-\text { labeled } \\
\text { macroaggregated albumin }\end{array}$ & \multirow[b]{2}{*}{$\begin{array}{l}\text { Ventilation/Perfusion }(\mathrm{V} / \mathrm{Q}) \text { scintigraphy to regional } \\
\text { inflammatory/airflow differences }\end{array}$} & {$[123,125]$} \\
\hline & Pulmonary ventilation & $\begin{array}{c}{ }^{81 \mathrm{~m}} \mathrm{Kr} \text { or }{ }^{133} \mathrm{Xe} \\
{ }^{99 \mathrm{~m}} \mathrm{Tc}-\text { labeled DTPA } \\
{ }^{99 \mathrm{~m}} \text { Tc-labeled carbon particles } \\
\text { (Technegas) }\end{array}$ & & [125] \\
\hline & Glucose metabolism & ${ }^{18}$ F-Flourodeoxyglucose (FDG) & Activated macrophage accumulation & {$[130-133]$} \\
\hline & $\begin{array}{l}\text { Translocator protein } \\
\text { (TSPO) receptors }\end{array}$ & ${ }^{11} \mathrm{C}-\mathrm{PK} 11195$ & Overexpressed on activated macrophages & [134] \\
\hline & \multirow{2}{*}{ MMPs } & ${ }^{18} \mathrm{~F}-\mathrm{IPFP}$ & \multirow{2}{*}{$\begin{array}{l}\text { Produced by active macrophages at the } \\
\text { inflammatory location }\end{array}$} & [135] \\
\hline & & ${ }^{99 \mathrm{~m}}$ Tc-labeled RP805 & & [136] \\
\hline \multirow{6}{*}{ Gastrointestinal } & Glucose metabolism & ${ }^{18}$ F-Flourodeoxyglucose (FDG) & Activated macrophage accumulation & {$[143,144]$} \\
\hline & CXCL8 receptor & ${ }^{99 \mathrm{~m}} \mathrm{Tc}-\mathrm{CXCL8}$ & Overexpression on activated neutrophils & [150] \\
\hline & Interleukin $1 \beta$ & ${ }^{89} \mathrm{Zr}-1 \alpha-\mathrm{IL}-1 \beta$ & $\begin{array}{l}\text { Secreted by immune cells indicating an } \\
\text { inflammatory response }\end{array}$ & [151] \\
\hline & CD11b & ${ }^{89} \mathrm{Zr}-\alpha-\mathrm{CD} 11 b$ & Pan-myeloid innate immune marker & [151] \\
\hline & $\mathrm{CD} 4$ & ${ }^{89} \mathrm{Zr}-\mathrm{GK} 1.5$ cys diabody (cDb) & $\begin{array}{c}\text { CD4 positive T-Cells characterize IBD } \\
\text { inflammatory response }\end{array}$ & [152] \\
\hline & EGFR & ${ }^{64} \mathrm{Cu}$-Cetuximab fragment-DOTA & Overexpression in inflammatory cells & [158] \\
\hline
\end{tabular}

\section{Cancer}

The relationship between inflammation, infection, the immune system, and cancer is complex and still under investigation. As tumor cells proliferate, they secrete many cytokines and chemokines, which recruit leukocytes, often causing an inflammatory response. These leukocytes, such as tumor-associated macrophages (TAMs), have a key role in the de- 
velopment of the tumor microenvironment [159]. As previously mentioned, ${ }^{18}$ F-FDG PET imaging is commonly used to visualize inflammation and cancer through increased glucose metabolism [160]. This can be problematic when trying to differentiate active cancers from inflammatory lesions, since both cancer and inflammation have increased perfusion and metabolic activity. CT imaging of glucose-functionalized gold nanoparticles (GF-GNPs) was used in preclinical mouse models to differentiate cancer and inflammation based on differences the vasculature (Figure 6). [161]. Similarly, enhanced MRI imaging of ultrasmall superparamagnetic iron oxide particles (USPIO) was able to differentiate between inflammatory lesions and tumors [162]. Recent advances in multispectral optoacoustic tomography (MSOT) provide a single imaging modality that is capable of differentiating cancer from solely inflammatory lesions by imaging multiple biomarkers simultaneously. Many different inflammatory biomarkers are described in this paper; the labeling of these markers with an NIR-sensitive fluorophore will allow for visualization with MSOT. The development of NIR-sensitive, tumor-targeted imaging probes is currently a main focus of MSOT research [112,163-165]. MSOT can differentiate between multiple NIR-sensitive agents through the spectral unmixing of unique spectral shapes. This suggests that as long as inflammatory and tumor targeted imaging agents are spectrally distinct, then it will be feasible to visualize cancer and inflammation simultaneously. The ability to identify a small nidus of cancer in the setting of larger inflammation has significant potential to result in earlier stage diagnoses for patients with pancreas or colorectal cancers in the setting of pancreatitis or inflammatory bowel disease.

A

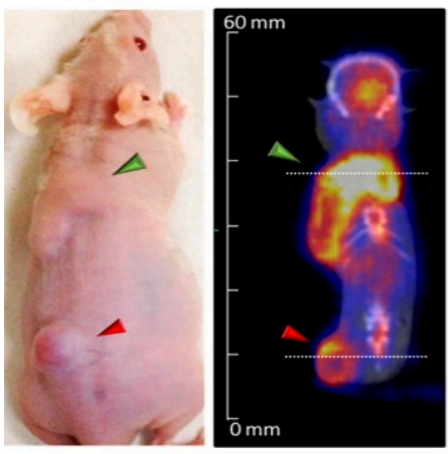

D

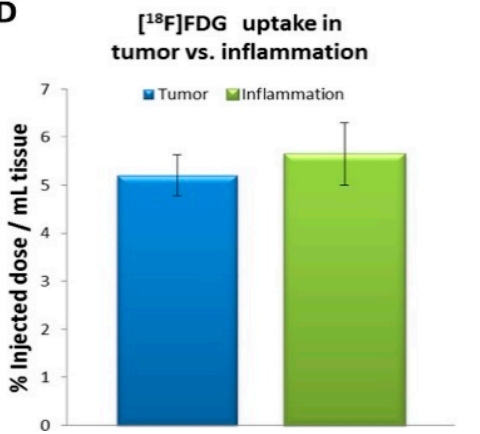

C

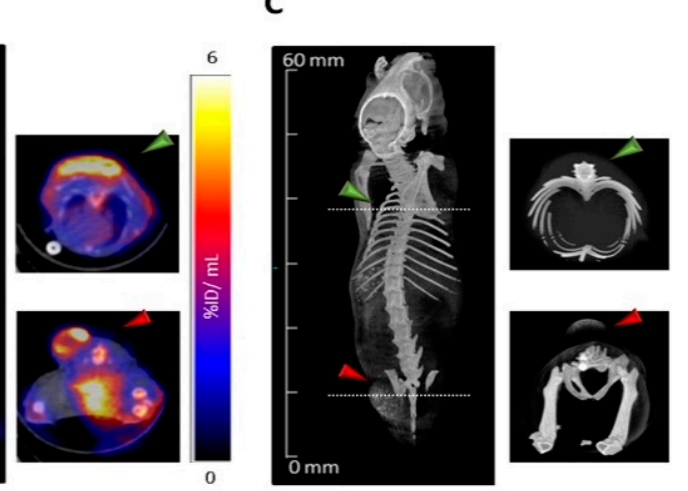

E

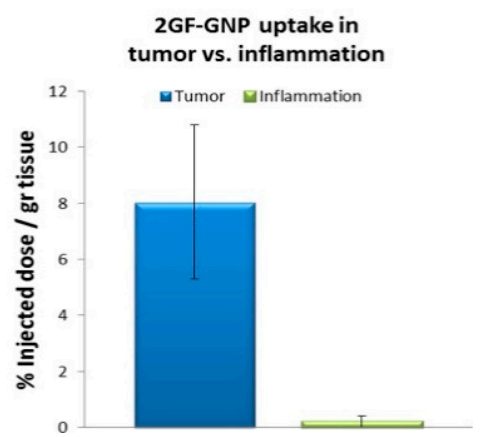

Figure 6. (A) Green arrowheads indicate the location of inflammation; red arrowheads indicate the location of A431 tumors. Images are taken after glucose-functionalized gold nanoparticles (2GF-GNP) injection. (B) ${ }^{18}$ F-FDG-PET/CT slice images of a representative mouse at $40-60 \mathrm{~min}$ post-injection. (C) CT surface-rendered images of the same mouse at $3.5 \mathrm{~h}$ post IV injection of 2GF-GNP. Quantification of ${ }^{18}$ F-FDG uptake and 2GF-GNP is shown in figures (D,E), respectively. ${ }^{18}$ F-FDG cannot differentiate between inflammatory lesions and tumor, while 2GF-GNP can [161]. 


\section{Imaging of Immunotherapy and Cellular Therapy}

Therapeutics in malignancy have recently undergone a paradigm shift, with movement from classic chemotherapeutics focused on the interruption of growth with toxic metabolites to medications and cellular therapeutics created to upregulate and/or direct host immune systems. The use of checkpoint inhibitors that activate and enhance T-cell function is extensively used in both solid tumors and hematologic areas. Recently, cellular therapeutics have also been approved for the direction of modified $\mathrm{T}$ cells to receptor targets in both leukemia and lymphoma. With this shift of therapy, the diagnostic platforms of CT and FDG-PET typically employed in cancer imaging are no longer capable of clearly differentiating an immune response from malignancy progression. For this reason, newer imaging agents are being studied to track and monitor disease and immune response in an upregulated immune system.

Recent efforts to improve diagnostics in this arena have focused on labeling $\mathrm{T}$ cells with PET probes to effectively track and identify effects of T-cell activation in cellular therapy and graft vs. host disease (GVHD). In mouse models, FLT-PET has been used to identify proliferation in the gut, correlating with immune recognition and response, in the setting of graft versus host disease [166]. Additionally, human T cells with anti-melanoma T-cell receptor have been transduced with F-L-MAU plus hdCKEmut PET probes to track and monitor response to melanoma lesions [167]. HSV1-TK transduced lymphocytes and CD19 CAR T cells with truncated epithelial growth factor receptors have been used to provide a platform for both the imaging and tracking of cellular response, as well as the incorporation of suicide genes for safety in the setting of severe $\mathrm{T}$ cell immunologic response or graft vs. host disease $[168,169]$. Recently, a rodent model has adopted the use of ${ }^{89} \mathrm{ZrDFO}-$ Inducible T-Cell COStimulator (ICOS)-monoclonal antibody (ICOS-ImmunoPET), taking advantage of elevated ICOS in activated CAR-T cells and thereby tracking response and localization [170]. Multiple studies using novel PET isotopes incorporated with either MRI or CT are under study to improve diagnostic accuracy in GVHD, cellular therapy, and immune-based therapeutics. (NCT03633955 FLT-CT in immunotherapy, F-18 ARA-G PET (NCT03367962, NCT03546556 FLT/MRI, NCT03802123 89Zr-Df-AB22M2C PET/CT CD8 TIL in solid tumor response). As therapeutics in cellular therapy advance, the allogeneic and immunologic sphere of cancer care expand into both hematologic and solid tumor areas, the capability to monitor, track, and quantitatively measure upregulated cellular components will be necessary, which will require the use of molecular imaging. In addition, future studies will also require molecular imaging to track the potential toxicity and early indications of efficacy.

\section{Image Analysis of Inflammatory Disease}

While this review focuses on the molecular imaging of inflammation for the diagnosis of inflammatory disease, there are many other methods for imaging inflammatory disease. Computer-assisted detection, segmentation, and classification of inflammatory tissues in the body have been the subject of several studies. These studies obtain images through various modalities (e.g., video endoscopy, infrared, or thermal imaging, etc.), and develop algorithms to recognize the characteristics of inflammation. While initial studies relied on classical machine learning and image analysis techniques, recent work heavily uses deep learning techniques. The traditional machine learning techniques can be characterized based on the extracted features and the type of classifier. The feature extraction techniques include gray-level co-occurrence matrix (GLCM), gray-level run-length (GLRL), speededup robust feature extraction (SURF), and dual-tree m-band wavelet transform (DTMBWT) algorithms [171-176]. The classifiers include support vector machine (SVM), k-nearest neighbor (K-NN), Random Forest (ensemble classifiers on three ensemble algorithms: bagging, Adaboost, and random subspace), and fuzzy c-means clustering (FCM) [177].

Recent advances in computational infrastructures and the availability of large datasets with ground truth have accelerated deep learning-based techniques. Their application to inflammation analysis from medical images has started. These studies rely on Convolu- 
tional Neural Networks (CNN) and CNN-based transfer learning methods (e.g., Residual network-50 (ResNet-50) and ResNet-34 [178], VGG-16 [179], and Inception-V3 [180], InceptionResnetV2 [181], and NASnet (mobile) [182]). Transfer learning methods employ pre-trained networks and retrain them with new domain-specific images but require a smaller number of images.

These methods were applied to various organs and inflammatory diseases, particularly rheumatoid arthritis (RA), which is the most common inflammatory and systemic connective tissue disease $[183,184]$. Some of the RA-related studies focus on hand images captured with different imaging modalities, such as infrared thermography sensor [185], thermal image [172], and digital anterior-posterior radiographs of hand images [186,187]. Some of these studies (e.g., [172,185]) use traditional image processing and machine learning algorithms such as thresholding, dilation, erosion, depth-first search (DFS), gray-level co-occurrence matrix (GLCM), and k-means. Other studies (e.g., $[186,187])$ use a CNNbased approach to segment and detect the RA regions. A review paper summarizes machine learning studies in rheumatic diseases [188]. Some studies go beyond detection and segmentation to scoring severity (Figure 7) $[173,189]$. Computerized analysis of inflammation was also applied to other inflammation diseases: paranasal sinus [190,191], chronic obstructive pulmonary disease (COPD) [177,192-194], celiac disease (CD) [195-198], inflammatory gastrointestinal lesions [176,199,200], varicose veins [201], myocarditis [202,203], and inflammatory brain abnormalities.

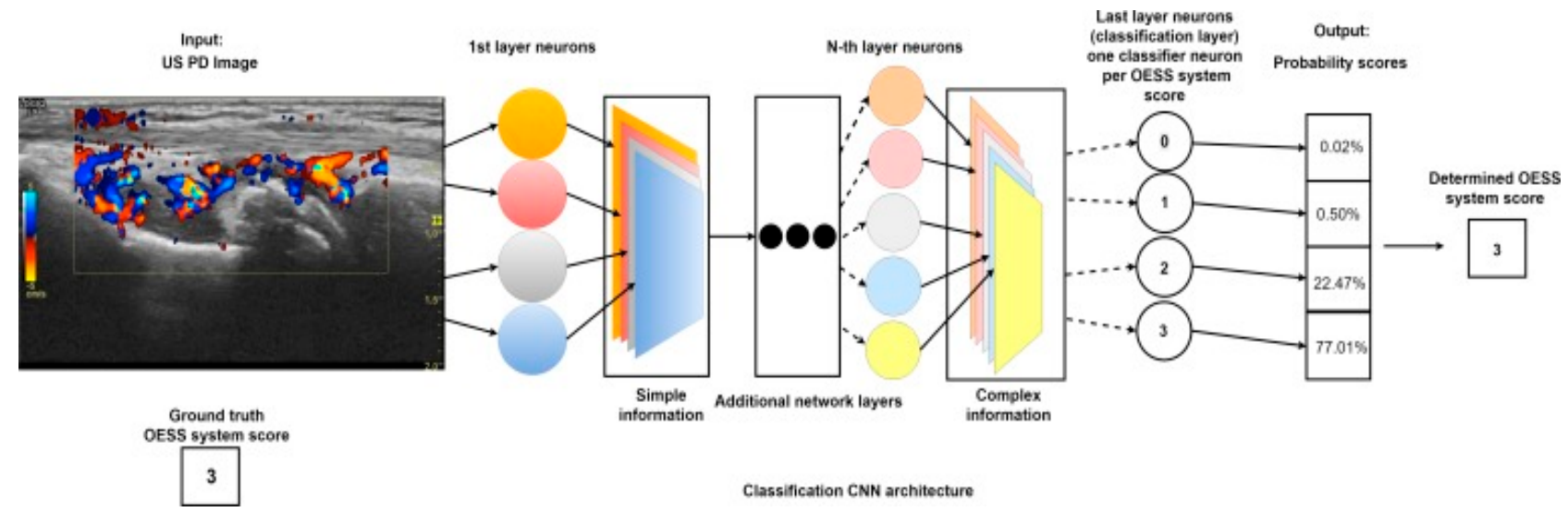

Figure 7. Schematic of the convolutional neural network that scores disease severity of RA based on an ultrasound color Doppler image of the wrist. Synovitis activity is evaluated and scored from 0-3, based on the OMERACT-EULAR Synovitis Scoring (OESS) System. After passing through each layer of the neural network, the classification neuron will map the resulting information to probability scores for each OESS score. The score with the highest probability is assigned to the US image [189].

Table 2 further demonstrates the broad spectrum of the imaging modalities and image analysis techniques employed to detect, segment, or classify inflammatory diseases. These studies report the performance of their algorithms with commonly used metrics of precision, accuracy, recall, specificity, F1 score, loss, the area under the curve (AUC), true positive rate (TPR), positive predictive value (PPV), and Dice coefficient. The performances vary from study to study. To give some idea of these performance values, the range of the Dice coefficient for sinusitis segmentation is $86-97 \%$, the accuracy is $78 \%$ to $92 \%$ [190,191,204]. For COPD and lung disease inflammation, and the accuracy ranges from $61 \%$ to $95 \%$ [177,192,193,195,205]. For $\mathrm{CD}$, the accuracy ranges from $79 \%$ to $97 \%$, while the sensitivity and specificity vary from $83 \%$ to $100 \%$ and $96 \%$ to $100 \%$, respectively [195-198]. 
Table 2. Inflammatory diseases, imaging modalities, and image analysis techniques of the studies stated in the reference column.

\begin{tabular}{|c|c|c|c|}
\hline Inflammatory Disease & Imaging Modalities & Image Analysis Techniques & Source \\
\hline Rheumatoid arthritis (RA) & $\begin{array}{c}\text { CT, } \\
\text { Thermal Image }\end{array}$ & $\begin{array}{l}\text { GLCM, KNN, Random Forest, } \\
\text { DFS, K-Means Clustering }\end{array}$ & {$[172,173,185-189,206]$} \\
\hline $\begin{array}{c}\text { Paranasal sinus } \\
\text { Chronic rhinosinusitis (CRI) }\end{array}$ & $\begin{array}{c}\text { CT, } \\
\text { Radiography Images }\end{array}$ & $\begin{array}{l}\text { CNN-Based Segmentation, } \\
\text { CNN-Based Transfer Learning }\end{array}$ & {$[190,191,204]$} \\
\hline $\begin{array}{c}\text { Chronic Obstructive } \\
\text { Pulmonary Disease, } \\
\text { Detecting Lung Disease, } \\
\text { Fibrotic and inflammatory } \\
\text { Lung Disease }\end{array}$ & $\begin{array}{c}\text { CT, } \\
\text { X-Ray Images } \\
\text { Microscopy Images (Whole Slide Images) }\end{array}$ & $\begin{array}{c}\text { GLCM, CNN, FCM, CNN-Based } \\
\text { Transfer Learning }\end{array}$ & {$[177,192-194,205]$} \\
\hline Celiac Disease (CD) & $\begin{array}{c}\text { Endoscopy Images } \\
\text { H\&E Duodenal Biopsy Images }\end{array}$ & $\begin{array}{c}\text { CNN-Based Transfer Learning } \\
\text { (Alexnet, VGG Nets, Resnet) } \\
\text { SVM, Bayesian }\end{array}$ & [195-198] \\
\hline $\begin{array}{l}\text { Inflammatory Bowel } \\
\text { Disease (IBD) } \\
\text { Inflammatory } \\
\text { Gastrointestinal Lesion }\end{array}$ & $\begin{array}{l}\text { Histology and Endoscopy Images } \\
\text { Colonoscopy Images }\end{array}$ & $\begin{array}{l}\text { CNN, SURF, CNN-Based Transfer } \\
\text { Learning (Resnet-152, } \\
\text { Inception-Resnet-V2) }\end{array}$ & {$[173,199,200,207]$} \\
\hline Varicose Vein & Multi-Scale Image & $\mathrm{CNN}$ & {$[201]$} \\
\hline Myocarditis & Cardiac MRI (CMR) & CNN, K-Means Clustering & {$[202,203]$} \\
\hline $\begin{array}{l}\text { Inflammatory Brain } \\
\text { Abnormalities } \\
\text { MS Segmentation }\end{array}$ & $\begin{array}{c}\text { H\&E Stain Image } \\
\text { Magnetic Resonance Imaging (MRI) }\end{array}$ & $\begin{array}{l}\text { R-CNN, DTMBWT, GLCM, GLRL, } \\
\text { SVM, KNN, Random Forest }\end{array}$ & {$[208-213]$} \\
\hline
\end{tabular}

Many reported studies need larger training datasets to better characterize the bias among different imaging modalities and to improve their performance and generalizability because of the variability in datasets. These studies also highlight the need for stronger clinical significance. For example, in a recent study of sinusitis, CNN scores were correlated with Lund-MacKay (LM) scores, which is the clinical visual score [190,214,215], while evaluating clinical significance was left as future work. Some studies also point out the need for further algorithmic development, such as the need for reliable methods for separating individual sinus cavities [190]. For COPD and inflammatory lung disease, microscopic image scoring algorithm accuracies are reported to be similar to those of pathologists; however, both computer algorithms and pathologists struggle in discriminating red blood cells from inflammatory cells when the staining was very dark [194]. For the CD, IBD, and inflammatory gastrointestinal lesion studies, it is often difficult to select the informative parts of the endoscopy and colonoscopy videos because of contributions from out-of-focus areas and image quality problems. For these studies, future work must be done to associate clinical findings with endoscopy results to have a fully automated system. Multiple sclerosis (MS) is a chronic inflammatory diseases of the brain which often requires segmentation of brain MRI images. The 3D patch-wise CNN approach has been used to segment the brain [211-213], but a large spatial variability makes the segmentation challenging. In addition, using 3D CNN needs more volumetric data (weights) to prevent overfitting.

\section{Conclusions}

Inflammatory diseases are extremely common and have high morbidity and mortality rates in severe cases. Early identification of molecular characteristics is the best chance at stopping irreversible damage. There is a demand for a non-invasive and highly specific way to image the pathophysiology of these diseases. As the immune system plays a huge role in inflammatory disease, immune cells and corresponding inflammatory cytokines are the primary targets in the molecular imaging of inflammatory disease. Advances in molecular imaging enable earlier detection through specific biomarkers that may be present before the onset of symptoms, leading to better patient care. 
Author Contributions: Writing-original draft preparation, M.A.J. Writing-review and editing, W.M.M., A.N.F., S.C. (Seda Camalan), M.N.G., J.H.-C., K.T.M., M.W.M., K.K.B., S.C. (Steven Carter), and W.E.G.; Figure 4 is original data from K.K.B.; writing-review and editing, funding acquisition, L.R.M. All authors have read and agreed to the published version of the manuscript.

Funding: This research and APC was funded by National Institutes of Health, grant numbers R01CA205941, R01CA212350, R01EB020125, and P30CA22552.

Conflicts of Interest: The authors declare no conflict of interest.

\begin{abstract}
Abbreviations
computed tomography: CT; magnetic resonance imaging: MRI; positron emission tomography: PET; ultrasound: US; superparamagnetic iron oxide nanoparticles: SPIONs; ultrasmall superparamagnetic iron oxide particles: USPIO; chemical exchange saturation transfer: CEST; cardiovascular disease: CVD; rheumatoid arthritis: RA; power Doppler ultrasound: PDUS; chronic obstructive pulmonary disease: COPD; diffusion-weighted MRI: DWI-MRI; gastrointestinal: GI; antibodies to citrullinated protein antigens: ACPAs; rheumatoid factor: RF; indocyanine green: ICG; inflammatory bowel disease: IBD; gray-level co-occurrence matrix: GLCM; gray-level run-length: GLRL; speededup robust feature extraction: SURF; and dual-tree m-band wavelet transform: DTMBWT; algorithms, support vector machine: SVM; k-nearest neighbor: K-NN; fuzzy c-means clustering: FCM.
\end{abstract}

\title{
References
}

1. MacRitchie, N.; Frleta-Gilchrist, M.; Sugiyama, A.; Lawton, T.; McInnes, I.B.; Maffia, P. Molecular Imaging of inflammationCurrent and Emerging Technologies for Diagnosis and Treatment. Pharmacol. Ther. 2020, 211, 107550. [CrossRef]

2. Chiu, S.; Bharat, A. Role of Monocytes and Macrophages in Regulating Immune Response Following Lung Transplantation. Curr. Opin. Organ Transpl. 2016, 21, 239-245. [CrossRef]

3. Malviya, G.; Galli, F.; Sonni, I.; Signore, A. Imaging T-lymphocytes in Inflammatory Diseases: A Nuclear Medicine Approach. Q. J. Nucl. Med. Mol. Imaging 2014, 58, 237-257.

4. Malviya, G.; Anzola, K.L.; Podestà, E.; Laganà, B.; Del Mastro, C.; Dierckx, R.A.; Scopinaro, F.; Signore, A. (99m)Tc-Labeled Rituximab for Imaging B Lymphocyte Infiltration in Inflammatory Autoimmune Disease Patients. Mol. Imaging Biol. 2012, 14, 637-646. [CrossRef]

5. Moroz, M.A.; Zhang, H.; Lee, J.; Moroz, E.; Zurita, J.; Shenker, L.; Serganova, I.; Blasberg, R.; Ponomarev, V. Comparative Analysis of T Cell Imaging with Human Nuclear Reporter Genes. J. Nucl. Med. 2015, 56, 1055-1060. [CrossRef]

6. Tavaré, R.; McCracken, M.N.; Zettlitz, K.A.; Salazar, F.B.; Olafsen, T.; Witte, O.N.; Wu, A.M. Immuno-PET of Murine T Cell Reconstitution Postadoptive Stem Cell Transplantation Using Anti-CD4 and Anti-CD8 Cys-Diabodies. J. Nucl. Med. 2015, 56, 1258-1264. [CrossRef]

7. Zalev, J.; Richards, L.M.; Clingman, B.A.; Harris, J.; Cantu, E.; Menezes, G.L.; Avila, C.A.; Bertrand, A.; Saenz, X.R.; Miller, S.C. Opto-Acoustic Imaging of Relative Blood Oxygen Saturation and Total Hemoglobin for Breast Cancer Diagnosis. J. Biomed. Opt. 2019, 24, 121915. [CrossRef]

8. Lee, J.; Hirano, Y.; Fukunaga, M.; Silva, A.C.; Duyn, J.H. On the Contribution of Deoxy-Hemoglobin to MRI Gray-White Matter Phase Contrast at High Field. Neuroimage 2010, 49, 193-198. [CrossRef]

9. Uematsu, T.; Yuen, S.; Yukisawa, S.; Aramaki, T.; Morimoto, N.; Endo, M.; Furukawa, H.; Uchida, Y.; Watanabe, J. Comparison of FDG PET and SPECT for Detection of Bone Metastases in Breast Cancer. Am. J. Roentgenol. 2005, 184, 1266-1273. [CrossRef]

10. Lee, N.; Choi, S.H.; Hyeon, T. Nano-Sized CT Contrast Agents. Adv. Mater. 2013, 25, 2641-2660. [CrossRef]

11. Bottrill, M.; Kwok, L.; Long, N.J. Lanthanides in Magnetic Resonance Imaging. Chem. Soc. Rev. 2006, 35, 557-571. [CrossRef] [PubMed]

12. Pearce, A.K.; O’Reilly, R.K. Insights into Active Targeting of Nanoparticles in Drug Delivery: Advances in Clinical Studies and Design Considerations for Cancer Nanomedicine. Bioconjug. Chem. 2019, 30, 2300-2311. [CrossRef] [PubMed]

13. Desar, I.M.E.; van Herpen, C.M.L.; van Laarhoven, H.W.M.; Barentsz, J.O.; Oyen, W.J.G.; van der Graaf, W.T.A. Beyond RECIST: Molecular and Functional Imaging Techniques for Evaluation of Response to Targeted Therapy. Cancer Treat. Rev. 2009, 35, 309-321. [CrossRef] [PubMed]

14. Gallagher, F.A. An Introduction to Functional and Molecular Imaging with MRI. Clin. Radiol. 2010, 65, 557-566. [CrossRef]

15. Caravan, P. Strategies for Increasing the Sensitivity of Gadolinium Based MRI Contrast Agents. Chem. Soc. Rev. 2006, 35, 512-523. [CrossRef]

16. Jin, R.; Lin, B.; Li, D.; Ai, H. Superparamagnetic Iron Oxide Nanoparticles for MR Imaging and Therapy: Design Considerations and Clinical Applications. Curr. Opin. Pharmacol. 2014, 18, 18-27. [CrossRef]

17. Wahajuddin, S.A. Superparamagnetic Iron Oxide Nanoparticles: Magnetic Nanoplatforms as Drug Carriers. Int. J. Nanomed. 2012, 7, 3445-3471. [CrossRef]

18. Neuwelt, A.; Sidhu, N.; Hu, C.-A.A.; Mlady, G.; Eberhardt, S.C.; Sillerud, L.O. Iron-Based Superparamagnetic Nanoparticle Contrast Agents for MRI of Infection and Inflammation. Am. J. Roentgenol. 2015, 204, W302-W313. [CrossRef] [PubMed] 
19. Manias, K.A.; Peet, A. What Is MR Spectroscopy? Arch. Dis. Child. Educ. Pract. Ed. 2018, 103, 213. [CrossRef] [PubMed]

20. Wu, B.; Warnock, G.; Zaiss, M.; Lin, C.; Chen, M.; Zhou, Z.; Mu, L.; Nanz, D.; Tuura, R.; Delso, G. An Overview of CEST MRI for Non-MR Physicists. EJNMMI Phys. 2016, 3, 19. [CrossRef]

21. Liu, G.; Bettegowda, C.; Qiao, Y.; Staedtke, V.; Chan, K.W.Y.; Bai, R.; Li, Y.; Riggins, G.J.; Kinzler, K.W.; Bulte, J.W.M.; et al. Noninvasive Imaging of Infection after Treatment with Tumor-Homing Bacteria Using Chemical Exchange Saturation Transfer (CEST) MRI. Magn. Reson. Med. 2013, 70, 1690-1698. [CrossRef]

22. Consolino, L.; Anemone, A.; Capozza, M.; Carella, A.; Irrera, P.; Corrado, A.; Dhakan, C.; Bracesco, M.; Longo, D.L. Non-Invasive Investigation of Tumor Metabolism and Acidosis by MRI-CEST Imaging. Front. Oncol. 2020, 10, 161. [CrossRef]

23. Chang, L.; Munsaka, S.M.; Kraft-Terry, S.; Ernst, T. Magnetic Resonance Spectroscopy to Assess Neuroinflammation and Neuropathic Pain. J. Neuroimmune Pharmacol. 2013, 8, 576-593. [CrossRef]

24. Chen, Y.Z.; Dai, Z.Z.; Shen, Z.W.; Lin, G.S.; Zhuang, C.Y.; Li, H.J.; Wu, R.H. Magnetic Resonance Imaging of Glutamate in Neuroinflammation. Radiol. Infect. Dis. 2016, 3, 92-97. [CrossRef]

25. Yanez Lopez, M.; Pardon, M.-C.; Baiker, K.; Prior, M.; Yuchun, D.; Agostini, A.; Bai, L.; Auer, D.P.; Faas, H.M. Myoinositol CEST Signal in Animals with Increased Iba-1 Levels in Response to an Inflammatory Challenge-Preliminary Findings. PLoS ONE 2019, 14, e0212002. [CrossRef]

26. Tarkin, J.M.; Dweck, M.R.; Evans, N.R.; Takx, R.A.P.; Brown, A.J.; Tawakol, A.; Fayad, Z.A.; Rudd, J.H.F. Imaging Atherosclerosis. Circ. Res. 2016, 118, 750-769. [CrossRef] [PubMed]

27. Van Camp, G. Cardiovascular Disease Prevention. Acta Clin/Belg. 2014, 69, 407-411. [CrossRef]

28. Francula-Zaninovic, S.; Nola, I.A. Management of Measurable Variable Cardiovascular Disease' Risk Factors. Curr. Cardiol. Rev. 2018, 14, 153-163. [CrossRef]

29. Jokinen, E. Obesity and Cardiovascular Disease. Minerva Pediatr. 2015, 67, 25-32.

30. Kondo, T.; Nakano, Y.; Adachi, S.; Murohara, T. Effects of Tobacco Smoking on Cardiovascular Disease. Circ. J. 2019, 83, 1980-1985. [CrossRef]

31. Virani, S.S.; Alonso, A.; Benjamin, E.J.; Bittencourt, M.S.; Callaway, C.W.; Carson, A.P.; Chamberlain, A.M.; Chang, A.R.; Cheng, S.; Delling, F.N.; et al. Heart Disease and Stroke Statistics-2020 Update: A Report from the American Heart Association. AHA/ASA J. 2020. [CrossRef]

32. Frostegård, J. Immunity, Atherosclerosis and Cardiovascular Disease. BMC Med. 2013, 11, 117. [CrossRef]

33. Rosenbaum, D.; Millon, A.; Fayad, Z.A. Molecular Imaging in Atherosclerosis: FDG PET. Curr. Atheroscler. Rep. 2012, 14, $429-437$. [CrossRef]

34. Syed, M.B.; Fletcher, A.J.; Forsythe, R.O.; Kaczynski, J.; Newby, D.E.; Dweck, M.R.; van Beek, E.J. Emerging Techniques in Atherosclerosis Imaging. Br. J. Radiol. 2019, 92, 20180309. [CrossRef]

35. Sandfort, V.; Lima Joao, A.C.; Bluemke, D.A. Noninvasive Imaging of Atherosclerotic Plaque Progression. Circ. Cardiovasc. Imaging 2015, 8, e003316. [CrossRef] [PubMed]

36. Detrano, R.; Guerci, A.D.; Carr, J.J.; Bild, D.E.; Burke, G.; Folsom, A.R.; Liu, K.; Shea, S.; Szklo, M.; Bluemke, D.A. Coronary Calcium as a Predictor of Coronary Events in Four Racial or Ethnic Groups. N. Engl. J. Med. 2008, 358, 1336-1345. [CrossRef]

37. Park, H.-B.; Heo, R.; Hartaigh, B.Ó.; Cho, I.; Gransar, H.; Nakazato, R.; Leipsic, J.; Mancini, G.B.J.; Koo, B.-K.; Otake, H.; et al. Atherosclerotic Plaque Characteristics by CT Angiography Identify Coronary Lesions That Cause Ischemia: A Direct Comparison to Fractional Flow Reserve. JACC Cardiovasc. Imaging 2015, 8, 1-10. [CrossRef]

38. Dunphy, M.P.; Freiman, A.; Larson, S.M.; Strauss, H.W. Association of Vascular 18F-FDG Uptake with Vascular Calcification. J. Nucl. Med. 2005, 46, 1278-1284.

39. Moore, K.J.; Tabas, I. Macrophages in the Pathogenesis of Atherosclerosis. Cell 2011, 145, 341-355. [CrossRef]

40. Tarkin, J.M.; Joshi, F.R.; Rudd, J.H.F. PET Imaging of Inflammation in Atherosclerosis. Nat. Rev. Cardiol. 2014, 11, 443-457. [CrossRef] [PubMed]

41. Lederman, R.; Raylman, R.; Fisher, S.; Kison, P.; San, H.; Nabel, E.; Wahl, R. Detection of Atherosclerosis Using a Novel Positron-Sensitive Probe and 18-fluorodeoxyglucose (FDG). Nucl. Med. Commun. 2001, 22, 747-753. [CrossRef]

42. Skagen, K.; Johnsrud, K.; Evensen, K.; Scott, H.; Krohg-Sørensen, K.; Reier-Nilsen, F.; Revheim, M.E.; Fjeld, J.G.; Skjelland, M.; Russell, D. Carotid Plaque Inflammation Assessed with (18)F-FDG PET/CT Is Higher in Symptomatic Compared with Asymptomatic Patients. Int. J. Stroke 2015, 10, 730-736. [CrossRef]

43. Vallabhajosula, S.; Machac, J.; Knesaurek, K.; Telsey, J.; Lipszyc, H.; Bastidas, D.; Zhao, Q.; Buchsbaum, M. Imaging Atherosclerotic Macrophage Density by Positron Emission Tomography Using F-18-fluorodeoxyglucose (FDG). J. Nucl. Med. 1996, $37,144$.

44. Yun, M.; Yeh, D.; Araujo, L.I.; Jang, S.; Newberg, A.; Alavi, A. F-18 FDG Uptake in the Large Arteries: A New Observation. Clin. Nucl. Med. 2001, 26, 314-319. [CrossRef] [PubMed]

45. Buck, A.K.; Reske, S.N. Cellular Origin and Molecular Mechanisms of 18F-FDG Uptake: Is There a Contribution of the Endothelium? J. Nucl. Med. 2004, 45, 461-463. [PubMed]

46. Rudd, J.H.; Warburton, E.; Fryer, T.D.; Jones, H.; Clark, J.; Antoun, N.; Johnstrom, P.; Davenport, A.P.; Kirkpatrick, P.J.; Arch, B.N. Imaging Atherosclerotic Plaque Inflammation with [18F]-fluorodeoxyglucose Positron Emission Tomography. Circulation 2002, 105, 2708-2711. [CrossRef]

47. Evans, N.R.; Tarkin, J.M.; Chowdhury, M.M.; Warburton, E.A.; Rudd, J.H.F. PET Imaging of Atherosclerotic Disease: Advancing Plaque Assessment from Anatomy to Pathophysiology. Curr. Atheroscler. Rep. 2016, 18, 30. [CrossRef] 
48. Mazurek, T.; Kobylecka, M.; Zielenkiewicz, M.; Kurek, A.; Kochman, J.; Filipiak, K.J.; Mazurek, K.; Huczek, Z.; Królicki, L.; Opolski, G. PET/CT Evaluation of 18 F-FDG Uptake in Pericoronary Adipose Tissue in Patients with Stable Coronary Artery Disease: Independent Predictor of Atherosclerotic Lesions' Formation? J. Nucl. Cardiol. 2017, 24, 1075-1084. [CrossRef]

49. Gullberg, G.T.; Shrestha, U.M.; Seo, Y. PET Imaging of Glucose and Fatty Acid Metabolism for NAFLD Patients. J. Nucl. Cardiol. 2020, 27, 1689-1697. [CrossRef]

50. Wykrzykowska, J.; Lehman, S.; Williams, G.; Parker, J.A.; Palmer, M.R.; Varkey, S.; Kolodny, G.; Laham, R. Imaging of Inflamed and Vulnerable Plaque in Coronary Arteries with 18F-FDG PET/CT in Patients with Suppression of Myocardial Uptake Using a Low-Carbohydrate, High-Fat Preparation. J. Nucl. Med. 2009, 50, 563-568. [CrossRef]

51. Bird, J.L.E.; Izquierdo-Garcia, D.; Davies, J.R.; Rudd, J.H.F.; Probst, K.C.; Figg, N.; Clark, J.C.; Weissberg, P.L.; Davenport, A.P.; Warburton, E.A. Evaluation of Translocator Protein Quantification as a Tool for Characterising Macrophage Burden in Human Carotid Atherosclerosis. Atherosclerosis 2010, 210, 388-391. [CrossRef]

52. Fujimura, Y.; Hwang, P.M.; Iii, H.T.; Kozloff, L.; Imaizumi, M.; Innis, R.B.; Fujita, M. Increased Peripheral Benzodiazepine Receptors in Arterial Plaque of Patients with Atherosclerosis: An Autoradiographic Study with [(3)H]PK 11195. Atherosclerosis 2008, 201, 108-111. [CrossRef] [PubMed]

53. Gaemperli, O.; Shalhoub, J.; Owen, D.R.; Lamare, F.; Johansson, S.; Fouladi, N.; Davies, A.H.; Rimoldi, O.E.; Camici, P.G. Imaging Intraplaque Inflammation in Carotid Atherosclerosis with 11C-PK11195 Positron Emission Tomography/Computed Tomography. Eur. Heart J. 2012, 33, 1902-1910. [CrossRef]

54. Pugliese, F.; Gaemperli, O.; Kinderlerer, A.R.; Lamare, F.; Shalhoub, J.; Davies, A.H.; Rimoldi, O.E.; Mason, J.C.; Camici, P.G. Imaging of Vascular Inflammation With [11C]-PK11195 and Positron Emission Tomography/Computed Tomography Angiography. J. Am. Coll. Cardiol. 2010, 56, 653-661. [CrossRef]

55. Boutin, H.; Murray, K.; Pradillo, J.; Maroy, R.; Smigova, A.; Gerhard, A.; Jones, P.A.; Trigg, W. 18F-GE-180: A Novel TSPO Radiotracer Compared to 11C-R-PK11195 in a Preclinical Model of Stroke. Eur. J. Nucl. Med. Mol. Imaging 2015, 42, 503-511. [CrossRef]

56. Rinne, P.; Hellberg, S.; Kiugel, M.; Virta, J.; Li, X.-G.; Käkelä, M.; Helariutta, K.; Luoto, P.; Liljenbäck, H.; Hakovirta, H. Comparison of Somatostatin Receptor 2-targeting PET Tracers in the Detection of Mouse Atherosclerotic Plaques. Mol. Imaging Biol. 2016, 18, 99-108. [CrossRef]

57. Tarkin, J.M.; Joshi, F.R.; Evans, N.R.; Chowdhury, M.M.; Figg, N.L.; Shah, A.V.; Starks, L.T.; Martin-Garrido, A.; Manavaki, R.; $\mathrm{Yu}$, E. Detection of Atherosclerotic Inflammation by 68Ga-DOTATATE PET Compared to [18F] FDG PET Imaging. J. Am. Coll. Cardiol. 2017, 69, 1774-1791. [CrossRef]

58. Pérez-Medina, C.; Fayad, Z.A.; Mulder, W.J.M. Atherosclerosis Immunoimaging by Positron Emission Tomography. Arter. Thromb. Vasc. Biol. 2020, 40, 865-873. [CrossRef]

59. Hyafil, F.; Pelisek, J.; Laitinen, I.; Schottelius, M.; Mohring, M.; Döring, Y.; van der Vorst, E.P.; Kallmayer, M.; Steiger, K.; Poschenrieder, A. Imaging the Cytokine Receptor CXCR4 in Atherosclerotic Plaques with the Radiotracer 68Ga-pentixafor for PET. J. Nucl. Med. 2017, 58, 499-506. [CrossRef]

60. Li, X.; Heber, D.; Leike, T.; Beitzke, D.; Lu, X.; Zhang, X.; Wei, Y.; Mitterhauser, M.; Wadsak, W.; Kropf, S.; et al. [68Ga]PentixaforPET/MRI for the Detection of Chemokine Receptor 4 Expression in Atherosclerotic Plaques. Eur. J. Nucl. Med. Mol. Imaging 2018, 45, 558-566. [CrossRef]

61. Weiberg, D.; Thackeray, J.T.; Daum, G.; Sohns, J.M.; Kropf, S.; Wester, H.-J.; Ross, T.L.; Bengel, F.M.; Derlin, T. Clinical Molecular Imaging of Chemokine Receptor CXCR4 Expression in Atherosclerotic Plaque Using 68Ga-pentixafor PET: Correlation with Cardiovascular Risk Factors and Calcified Plaque Burden. J. Nucl. Med. 2018, 59, 266-272. [CrossRef]

62. Marsch, E.; Sluimer, J.C.; Daemen, M.J. Hypoxia in Atherosclerosis and Inflammation. Curr. Opin. Lipidol. 2013, 24, 393-400. [CrossRef]

63. Joshi, F.R.; Manavaki, R.; Fryer, T.D.; Figg, N.L.; Sluimer, J.C.; Aigbirhio, F.I.; Davenport, A.P.; Kirkpatrick, P.J.; Warburton, E.A.; Rudd, J.H.F. Vascular Imaging with (18)F-Fluorodeoxyglucose Positron Emission Tomography Is Influenced by Hypoxia. J. Am. Coll. Cardiol. 2017, 69, 1873-1874. [CrossRef]

64. Mateo, J.; Izquierdo-Garcia, D.; Badimon, J.J.; Fayad, Z.A.; Fuster, V. Noninvasive Assessment of Hypoxia in Rabbit Advanced Atherosclerosis Using ${ }^{18}$ F-fluoromisonidazole Positron Emission Tomographic Imaging. Circ. Cardiovasc. Imaging 2014, 7, 312-320. [CrossRef]

65. Silvola, J.M.; Saraste, A.; Forsback, S.; Laine, V.J.; Saukko, P.; Heinonen, S.E.; Ylä-Herttuala, S.; Roivainen, A.; Knuuti, J. Detection of Hypoxia by [18F]EF5 in Atherosclerotic Plaques in Mice. Arter. Thromb. Vasc. Biol. 2011, 31, 1011-1015. [CrossRef]

66. Smolen, J.S.; Aletaha, D.; McInnes, I.B. Rheumatoid Arthritis. Lancet 2016, 388, 2023-2038. [CrossRef]

67. Aletaha, D.; Smolen, J.S. Diagnosis and Management of Rheumatoid Arthritis: A Review. JAMA 2018, 320, 1360-1372. [CrossRef]

68. Verheul, M.; Fearon, U.; Trouw, L.; Veale, D. Biomarkers for Rheumatoid and Psoriatic Arthritis. Clin. Immunol. 2015, 161, 2-10. [CrossRef]

69. Chang, K.; Yang, S.M.; Kim, S.H.; Han, K.H.; Park, S.J.; Shin, J.I. Smoking and Rheumatoid Arthritis. Int. J. Mol. Sci. 2014, 15, 22279-22295. [CrossRef]

70. Cheng, L.; Qian, L.; Xu, Z.-Z.; Tan, Y.; Luo, C.-Y. Aromatic Hydrocarbon Receptor Provides a Link between Smoking and Rheumatoid Arthritis in Peripheral Blood Mononuclear Cells. Clin. Exp. Rheumatol. 2019, 37, 445-449. 
71. Dar, L.; Tiosano, S.; Watad, A.; Bragazzi, N.L.; Zisman, D.; Comaneshter, D.; Cohen, A.; Amital, H. Are Obesity and Rheumatoid Arthritis Interrelated? Int. J. Clin. Pract. 2018, 72, e13045. [CrossRef] [PubMed]

72. Nikiphorou, E.; Norton, S.; Young, A.; Dixey, J.; Walsh, D.; Helliwell, H.; Kiely, P. Early Rheumatoid Arthritis Study and the Early Rheumatoid Arthritis Network. The Association of Obesity with Disease Activity, Functional Ability and Quality of Life in Early Rheumatoid Arthritis: Data from the Early Rheumatoid Arthritis Study/Early Rheumatoid Arthritis Network UK Prospective Cohorts. Rheumatology 2018, 57, 1194-1202.

73. Tolusso, B.; Gigante, M.R.; Alivernini, S.; Petricca, L.; Fedele, A.L.; Di Mario, C.; Aquilanti, B.; Magurano, M.R.; Ferraccioli, G.; Gremese, E. Chemerin and PEDF Are Metaflammation-Related Biomarkers of Disease Activity and Obesity in Rheumatoid Arthritis. Front. Med. 2018, 5. [CrossRef] [PubMed]

74. Grygielska, J.; Raciborski, F.; Kłak, A.; Owoc, J. The Impact of Nutrition and Generally Available Products Such as Nicotine and Alcohol on Rheumatoid Arthritis-Review of the Literature. Reumatologia 2018, 56, 121. [CrossRef] [PubMed]

75. Hu, Y.; Sparks, J.A.; Malspeis, S.; Costenbader, K.H.; Hu, F.B.; Karlson, E.W.; Lu, B. Long-Term Dietary Quality and Risk of Developing Rheumatoid Arthritis in Women. Ann. Rheum. Dis. 2017, 76, 1357-1364. [CrossRef]

76. Lu, B.; Solomon, D.H.; Costenbader, K.H.; Karlson, E.W. Alcohol Consumption and Risk of Incident Rheumatoid Arthritis in Women: A Prospective Study. Arthritis Rheumatol. 2014, 66, 1998-2005. [CrossRef] [PubMed]

77. De Brito Rocha, S.; Baldo, D.C.; Andrade, L.E.C. Clinical and Pathophysiologic Relevance of Autoantibodies in Rheumatoid Arthritis. Adv. Rheumatol. 2019, 59, 2. [CrossRef]

78. Demoruelle, M.K.; Deane, K. Antibodies to Citrullinated Protein Antigens (ACPAs): Clinical and Pathophysiologic Significance. Curr. Rheumatol. Rep. 2011, 13, 421-430. [CrossRef]

79. Moeez, S.; John, P.; Bhatti, A. Anti-Citrullinated Protein Antibodies: Role in Pathogenesis of RA and Potential as a Diagnostic Tool. Rheumatol. Int. 2013, 33, 1669-1673. [CrossRef]

80. Ingegnoli, F.; Castelli, R.; Gualtierotti, R. Rheumatoid Factors: Clinical Applications. Dis. Markers 2013, 35, 726598. [CrossRef]

81. Aletaha, D.; Neogi, T.; Silman, A.J.; Funovits, J.; Felson, D.T.; Bingham, C.O., III; Birnbaum, N.S.; Burmester, G.R.; Bykerk, V.P.; Cohen, M.D.; et al. 2010 Rheumatoid Arthritis Classification Criteria: An American College of Rheumatology/European League Against Rheumatism Collaborative Initiative. Arthritis Rheum. 2010, 62, 2569-2581. [CrossRef]

82. Joshua, F.; Edmonds, J.; Lassere, M. Power Doppler Ultrasound in Musculoskeletal Disease: A Systematic Review. Semin. Arthritis Rheum. 2006, 36, 99-108. [CrossRef] [PubMed]

83. Shaloo Bhasin, P.P.C. The Role of Power Doppler Ultrasonography as Disease Activity Marker in Rheumatoid Arthritis. Dis. Markers 2015, 2015. [CrossRef]

84. Yamanishi, Y.; Firestein, G.S. Pathogenesis of Rheumatoid Arthritis: The Role of Synoviocytes. Rheum. Dis. Clin. N. Am. 2001, 27, 355-371. [CrossRef]

85. Ostrowska, M.; Maśliński, W.; Prochorec-Sobieszek, M.; Nieciecki, M.; Sudoł-Szopińska, I. Cartilage and Bone Damage in Rheumatoid Arthritis. Reumatologia 2018, 56, 111-120. [CrossRef]

86. Yoshitomi, H. Regulation of Immune Responses and Chronic Inflammation by Fibroblast-Like Synoviocytes. Front. Immunol. 2019, 10. [CrossRef]

87. Nehoff, H.; Parayath, N.N.; Domanovitch, L.; Taurin, S.; Greish, K. Nanomedicine for Drug Targeting: Strategies beyond the Enhanced Permeability and Retention Effect. Int. J. Nanomed. 2014, 9, 2539-2555. [CrossRef]

88. Butoescu, N.; Seemayer, C.A.; Foti, M.; Jordan, O.; Doelker, E. Dexamethasone-Containing PLGA Superparamagnetic Microparticles as Carriers for the Local Treatment of Arthritis. Biomaterials 2009, 30, 1772-1780. [CrossRef]

89. Wu, L.; Shen, S. What Potential do Magnetic Iron Oxide Nanoparticles Have for the Treatment of Rheumatoid Arthritis? Nanomedicine 2019, 14, 927-930. [CrossRef]

90. Beckers, C.; Ribbens, C.; André, B.; Marcelis, S.; Kaye, O.; Mathy, L.; Kaiser, M.J.; Hustinx, R.; Foidart, J.; Malaise, M.G. Assessment of Disease Activity in Rheumatoid Arthritis with (18)F-FDG PET. J. Nucl. Med. 2004, 45, 956-964.

91. Chaudhari, A.J.; Ferrero, A.; Godinez, F.; Yang, K.; Shelton, D.K.; Hunter, J.C.; Naguwa, S.M.; Boone, J.M.; Raychaudhuri, S.P.; Badawi, R.D. High-Resolution 18F-FDG PET/CT for Assessing Disease Activity in Rheumatoid and Psoriatic Arthritis: Findings of a Prospective Pilot Study. Br. J. Radiol. 2016, 89, 20160138. [CrossRef]

92. Kubota, K.; Yamashita, H.; Mimori, A. Clinical Value of FDG-PET/CT for the Evaluation of Rheumatic Diseases: Rheumatoid Arthritis, Polymyalgia Rheumatica, and Relapsing Polychondritis. Semin. Nucl. Med. 2017, 47, 408-424. [CrossRef] [PubMed]

93. Chandrupatla, D.; Molthoff, C.F.M.; Lammertsma, A.A.; van der Laken, C.J.; Jansen, G. The Folate Receptor $\beta$ as a MacrophageMediated Imaging and Therapeutic Target in Rheumatoid Arthritis. Drug Deliv. Transl. Res. 2019, 9, 366-378. [CrossRef] [PubMed]

94. Xia, W.; Hilgenbrink, A.R.; Matteson, E.L.; Lockwood, M.B.; Cheng, J.-X.; Low, P.S. A Functional Folate Receptor Is Induced during Macrophage Activation and Can Be Used to Target Drugs to Activated Macrophages. Blood J. Am. Soc. Hematol. 2009, 113, 438-446. [CrossRef]

95. De Visser, H.M.; Korthagen, N.M.; Müller, C.; Ramakers, R.M.; Krijger, G.C.; Lafeber, F.P.J.G.; Beekman, F.J.; Mastbergen, S.C.; Weinans, H. Imaging of Folate Receptor Expressing Macrophages in the Rat Groove Model of Osteoarthritis: Using a New DOTA-Folate Conjugate. Cartilage 2018, 9, 183-191. [CrossRef] 
96. Van Der Heijden, J.W.; Oerlemans, R.; Dijkmans, B.A.; Qi, H.; Laken, C.J.V.D.; Lems, W.F.; Jackman, A.L.; Kraan, M.C.; Tak, P.P.; Ratnam, M. Folate Receptor $\beta$ as a Potential Delivery Route for Novel Folate Antagonists to Macrophages in the Synovial Tissue of Rheumatoid Arthritis Patients. Arthritis Rheum. 2009, 60, 12-21. [CrossRef] [PubMed]

97. Verweij, N.J.F.; Yaqub, M.; Bruijnen, S.T.G.; Pieplenbosch, S.; Ter Wee, M.M.; Jansen, G.; Chen, Q.; Low, P.S.; Windhorst, A.D.; Lammertsma, A.A.; et al. First in Man Study of [(18)F]fluoro-PEG-folate PET: A Novel Macrophage Imaging Technique to Visualize Rheumatoid Arthritis. Sci. Rep. 2020, 10, 1047. [CrossRef]

98. Chen, W.-T.; Mahmood, U.; Weissleder, R.; Tung, C.-H. Arthritis Imaging Using a Near-Infrared Fluorescence Folate-Targeted Probe. Arthritis Res. Ther. 2005, 7, R310-R317. [CrossRef]

99. Put, S.; Westhovens, R.; Lahoutte, T.; Matthys, P. Molecular Imaging of Rheumatoid Arthritis: Emerging Markers, Tools, and Techniques. Arthritis Res. Ther. 2014, 16, 208. [CrossRef]

100. Chapman, P.T.; Jamar, F.; Keelan, E.T.; Peters, A.M.; Haskard, D.O. Use of a Radiolabeled Monoclonal Antibody against E-Selectin for Imaging of Endothelial Activation in Rheumatoid Arthritis. Arthritis Rheum. 1996, 39, 1371-1375. [CrossRef]

101. Gompels, L.L.; Madden, L.; Lim, N.H.; Inglis, J.J.; McConnell, E.; Vincent, T.L.; Haskard, D.O.; Paleolog, E.M. In Vivo Fluorescence Imaging of E-Selectin: Quantitative Detection of Endothelial Activation in a Mouse Model of Arthritis. Arthritis Rheum. 2011, 63, 107-117. [CrossRef]

102. Jamar, F.; Houssiau, F.; Devogelaer, J.P.; Chapman, P.; Haskard, D.; Beaujean, V.; Beckers, C.; Manicourt, D.H.; Peters, A. Scintigraphy Using a Technetium 99m-Labelled Anti-E-Selectin Fab Fragment in Rheumatoid Arthritis. Rheumatology 2002, 41, 53-61. [CrossRef] [PubMed]

103. Ryu, J.H.; Lee, A.; Chu, J.U.; Koo, H.; Ko, C.Y.; Kim, H.S.; Yoon, S.Y.; Kim, B.S.; Choi, K.; Kwon, I.C.; et al. Early Diagnosis of Arthritis in Mice with Collagen-Induced Arthritis, Using a Fluorogenic Matrix Metalloproteinase 3-Specific Polymeric Probe. Arthritis Rheum. 2011, 63, 3824-3832. [CrossRef] [PubMed]

104. Schrigten, D.; Breyholz, H.-J.; Wagner, S.; Hermann, S.; Schober, O.; Schäfers, M.; Haufe, G.; Kopka, K. A New Generation of Radiofluorinated Pyrimidine-2,4,6-triones as MMP-Targeted Radiotracers for Positron Emission Tomography. J. Med. Chem. 2012, 55, 223-232. [CrossRef]

105. Bruijnen, S.; Tsang-A-Sjoe, M.; Raterman, H.; Ramwadhdoebe, T.; Vugts, D.; van Dongen, G.; Huisman, M.; Hoekstra, O.; Tak, P.-P.; Voskuyl, A.; et al. B-Cell Imaging with Zirconium-89 Labelled Rituximab PET-CT at Baseline Is Associated with Therapeutic Response 24 Weeks after Initiation of Rituximab Treatment in Rheumatoid Arthritis Patients. Arthritis Res. Ther. 2016, 18, 266. [CrossRef]

106. Tran, L.; Huitema, A.D.; van Rijswijk, M.H.; Dinant, H.J.; Baars, J.W.; Beijnen, J.H.; Vogel, W.V. CD20 Antigen Imaging with 124I-rituximab PET/CT in Patients with Rheumatoid Arthritis. Hum. Antibodies 2011, 20, 29-35. [CrossRef]

107. Barrera, P.; Oyen, W.; Boerman, O.; Van Riel, P. Scintigraphic Detection of Tumour Necrosis Factor in Patients with Rheumatoid Arthritis. Ann. Rheum. Dis. 2003, 62, 825-828. [CrossRef]

108. Maini, R.N.; Feldmann, M. How Does Infliximab Work in Rheumatoid Arthritis? Arthritis Res. Ther. 2002, 4, S22-S28. [CrossRef]

109. Roimicher, L.; Lopes, F.P.; de Souza, S.A.; Mendes, L.F.; Domingues, R.C.; da Fonseca, L.M.; Gutfilen, B. 99mTc-anti-TNF- $\alpha$ Scintigraphy in RA: A Comparison Pilot Study with MRI and Clinical Examination. Rheumatology 2011, 50, 2044-2050. [CrossRef]

110. Barthel, S.R.; Gavino, J.D.; Descheny, L.; Dimitroff, C.J. Targeting Selectins and Selectin Ligands in Inflammation and Cancer. Expert Opin. Ther. Targets 2007, 11, 1473-1491. [CrossRef]

111. Licha, K.; Welker, P.; Weinhart, M.; Wegner, N.; Kern, S.; Reichert, S.; Gemeinhardt, I.; Weissbach, C.; Ebert, B.; Haag, R.; et al. Fluorescence Imaging with Multifunctional Polyglycerol Sulfates: Novel Polymeric near-IR Probes Targeting Inflammation. Bioconjug. Chem. 2011, 22, 2453-2460. [CrossRef]

112. MacCuaig, W.M.; Jones, M.A.; Abeyakoon, O.; McNally, L.R. Development of Multispectral Optoacoustic Tomography as a Clinically Translatable Modality for Cancer Imaging. Radiol. Imaging Cancer 2020, 2, e200066. [CrossRef] [PubMed]

113. Beziere, N.; von Schacky, C.; Kosanke, Y.; Kimm, M.; Nunes, A.; Licha, K.; Aichler, M.; Walch, A.; Rummeny, E.J.; Ntziachristos, V.; et al Optoacoustic Imaging and Staging of Inflammation in a Murine Model of Arthritis. Arthritis Rheumatol. 2014, 66, 2071-2078. [CrossRef] [PubMed]

114. Criner, R.N.; Han, M.K. COPD Care in the 21st Century: A Public Health Priority. Respir. Care 2018, 63, 591-600. [CrossRef] [PubMed]

115. Athanazio, R. Airway Disease: Similarities and Differences between Asthma, COPD and Bronchiectasis. Clinics 2012, 67, 1335-1343. [CrossRef]

116. Rovina, N.; Koutsoukou, A.; Koulouris, N.G. Inflammation and Immune Response in COPD: Where Do We Stand? Mediat. Inflamm. 2013, 2013, 413735. [CrossRef]

117. Myc, L.A.; Shim, Y.M.; Laubach, V.E.; Dimastromatteo, J. Role of Medical and Molecular Imaging in COPD. Clin. Transl. Med. 2019, 8, 12. [CrossRef]

118. Sverzellati, N.; Molinari, F.; Pirronti, T.; Bonomo, L.; Spagnolo, P.; Zompatori, M. New Insights on COPD Imaging via CT and MRI. Int. J. Chron. Obstruct. Pulmon. Dis. 2007, 2, 301-312. [PubMed]

119. Shah, P.L.; Herth, F.J.; van Geffen, W.H.; Deslee, G.; Slebos, D.-J. Lung Volume Reduction for Emphysema. Lancet Respir. Med. 2017, 5, 147-156. [CrossRef]

120. Sharafkhaneh, A.; Hanania, N.A.; Kim, V. Pathogenesis of Emphysema: From the Bench to the Bedside. Proc. Am. Thorac. Soc. 2008, 5, 475-477. [CrossRef] 
121. Izquierdo-Alonso, J.L.; Rodriguez-Gonzálezmoro, J.M.; de Lucas-Ramos, P.; Unzueta, I.; Ribera, X.; Antón, E.; Martín, A. Prevalence and Characteristics of Three Clinical phenotypes of Chronic Obstructive Pulmonary Disease (COPD). Respir. Med. 2013, 107, 724-731. [CrossRef] [PubMed]

122. Lahousse, L.; Seys, L.J.M.; Joos, G.F.; Franco, O.H.; Stricker, B.H.; Brusselle, G.G. Epidemiology and Impact of Chronic Bronchitis in Chronic obstructive Pulmonary Disease. Eur. Respir. J. 2017, 50, 1602470. [CrossRef] [PubMed]

123. Mortensen, J.; Berg, R.M.G. Lung Scintigraphy in COPD. Semin. Nucl. Med. 2019, 49, 16-21. [CrossRef]

124. Magnant, J.; Vecellio, L.; de Monte, M.; Grimbert, D.; Valat, C.; Boissinot, E.; Guilloteau, D.; Lemarié, E.; Diot, P. Comparative Analysis of Different Scintigraphic Approaches to Assess Pulmonary Ventilation. J. Aerosol Med. 2006, 19, 148-159. [CrossRef] [PubMed]

125. Brudin, L.H.; Rhodes, C.G.; Valind, S.O.; Buckingham, P.D.; Jones, T.; Hughes, J.M. Regional Structure-Function Correlations in Chronic Obstructive Lung Disease Measured with Positron Emission Tomography. Thorax 1992, 47, 914-921. [CrossRef] [PubMed]

126. Milne, S.; King, G.G. Advanced Imaging in COPD: Insights into Pulmonary Pathophysiology. J. Thorac. Dis. 2014, 6, 1570-1585. [CrossRef]

127. Roos, J.E.; McAdams, H.P.; Kaushik, S.S.; Driehuys, B. Hyperpolarized Gas MR Imaging: Technique and Applications. Magn. Reson. Imaging Clin. N. Am. 2015, 23, 217-229. [CrossRef]

128. Fain, S.B.; Panth, S.R.; Evans, M.D.; Wentland, A.L.; Holmes, J.H.; Korosec, F.R.; O’Brien, M.J.; Fountaine, H.; Grist, T.M. Early Emphysematous Changes in Asymptomatic Smokers: Detection with 3He MR Imaging. Radiology 2006, 239, 875-883. [CrossRef]

129. Tafti, S.; Garrison, W.J.; Mugler, J.P.; Shim, Y.M.; Altes, T.A.; Mata, J.F.; de Lange, E.E.; Cates, G.D.; Ropp, A.M.; Wang, C.; et al. Emphysema Index Based on Hyperpolarized 3He or 129Xe Diffusion MRI: Performance and Comparison with Quantitative CT and Pulmonary Function Tests. Radiology 2020, 297, 201-210. [CrossRef]

130. Coello, C.; Fisk, M.; Mohan, D.; Wilson, F.J.; Brown, A.P.; Polkey, M.I.; Wilkinson, I.; Tal-Singer, R.; Murphy, P.S.; Cheriyan, J.; et al. Quantitative Analysis of Dynamic (18)F-FDG PET/CT for Measurement of Lung Inflammation. EJNMMI Res. $2017,7,47$. [CrossRef] [PubMed]

131. Kothekar, E.; Borja, A.J.; Gerke, O.; Werner, T.J.; Alavi, A.; Revheim, M.-E. Assessing Respitatory Muscle Activity with (18)F-FDGPET/CT in Patients with COPD. Am. J. Nucl. Med. Mol. Imaging 2019, 9, 309-315. [PubMed]

132. Pournazari, K.; Jahangiri, P.; Al-zaghal, A.; Arani, L.; Mehdizadeh Seraj, S.; Werner, T.; Alavi, A.; Torigian, D. Feasibility of Using Global Lung FDG Uptake in COPD Patients on PET/CT to Assess the Degree of Pulmonary Inflammation in Relation to Emphysema Severity. J. Nucl. Med. 2018, 59, 517.

133. Subramanian, D.R.; Jenkins, L.; Edgar, R.; Quraishi, N.; Stockley, R.A.; Parr, D.G. Assessment of Pulmonary Neutrophilic Inflammation in Emphysema by Quantitative Positron Emission Tomography. Am. J. Respir. Crit. Care Med. 2012, 186, $1125-1132$. [CrossRef] [PubMed]

134. Jones, H.A.; Marino, P.S.; Shakur, B.H.; Morrell, N.W. In Vivo Assessment of Lung Inflammatory Cell Activity in Patients with COPD and Asthma. Eur. Respir. J. 2003, 21, 567-573. [CrossRef]

135. Kondo, N.; Temma, T.; Aita, K.; Shimochi, S.; Koshino, K.; Senda, M.; Iida, H. Development of Matrix Metalloproteinase-Targeted Probes for Lung Inflammation Detection with Positron Emission Tomography. Sci. Rep. 2018, 8, 1347. [CrossRef]

136. Golestani, R.; Razavian, M.; Ye, Y.; Zhang, J.; Jung, J.-J.; Toczek, J.; Gona, K.; Kim, H.-Y.; Elias, J.A.; Lee, C.G.; et al. Matrix Metalloproteinase-Targeted Imaging of Lung Inflammation and Remodeling. J. Nucl. Med. 2017, 58, 138-143. [CrossRef]

137. Ady, J.; Fong, Y. Imaging for Infection: From Visualization of Inflammation to Visualization of Microbes. Surg. Infect. (Larchmt) 2014, 15, 700-707. [CrossRef]

138. Frickenstein, A.N.; Jones, M.A.; Behkam, B.; McNally, L.R. Imaging Inflammation and Infection in the Gastrointestinal Tract. Int. J. Mol. Sci. 2019, 21, 243. [CrossRef]

139. Alatab, S.; Sepanlou, S.G.; Ikuta, K.; Vahedi, H.; Bisignano, C.; Safiri, S.; Sadeghi, A.; Nixon, M.R.; Abdoli, A.; Abolhassani, H.; et al. The Global, Regional, and National Burden of Inflammatory Bowel Disease in 195 Countries and Territories, 1990-2017: A Systematic Analysis for the Global Burden of Disease Study 2017. Lancet Gastroenterol. Hepatol. 2020, 5, 17-30. [CrossRef]

140. Molodecky, N.A.; Kaplan, G.G. Environmental Risk Factors for Inflammatory Bowel Disease. Gastroenterol. Hepatol. (NY) 2010, 6, 339-346.

141. Mattar, M.C.; Lough, D.; Pishvaian, M.J.; Charabaty, A. Current Management of Inflammatory Bowel Disease and Colorectal Cancer. Gastrointest. Cancer Res. 2011, 4, 53-61. [PubMed]

142. Kilcoyne, A.; Kaplan, J.L.; Gee, M.S. Inflammatory Bowel Disease Imaging: Current Practice and Future Directions. World J. Gastroenterol. 2016, 22, 917-932. [CrossRef] [PubMed]

143. Brewer, S.; McPherson, M.; Fujiwara, D.; Turovskaya, O.; Ziring, D.; Chen, L.; Takedatsu, H.; Targan, S.R.; Wei, B.; Braun, J. Molecular Imaging of Murine Intestinal Inflammation with 2-deoxy-2-[18F]fluoro-D-glucose and Positron Emission Tomography. Gastroenterology 2008, 135, 744-755. [CrossRef]

144. Pio, B.S.; Byrne, F.R.; Aranda, R.; Boulay, G.; Spicher, K.; Song, M.H.; Birnbaumer, L.; Phelps, M.E.; Czernin, J.; Silverman, D.H. Noninvasive Quantification of Bowel Inflammation Through Positron Emission Tomography Imaging of 2-deoxy-2-[18F]fluoroD-glucose-labeled White Blood Cells. Mol. Imaging Biol. 2003, 5, 271-277. [CrossRef]

145. Gotthardt, M.; Bleeker-Rovers, C.P.; Boerman, O.C.; Oyen, W.J. Imaging of Inflammation by PET, Conventional Scintigraphy, and Other Imaging Techniques. J. Nucl. Med. 2010, 51, 1937-1949. [CrossRef]

146. Catalano, O.A.; Wu, V.; Mahmood, U.; Signore, A.; Vangel, M.; Soricelli, A.; Salvatore, M.; Gervais, D.; Rosen, B.R. Diagnostic Performance of PET/MR in the Evaluation of Active Inflammation in Crohn Disease. Am. J. Nucl. Med. Mol. Imaging 2018, 8, 62-69. 
147. Le Fur, M.; Zhou, I.Y.; Catalano, O.; Caravan, P. Toward Molecular Imaging of Intestinal Pathology. Inflamm. Bowel Dis. 2020, 26, 1470-1484. [CrossRef]

148. Perlman, S.B.; Hall, B.S.; Reichelderfer, M. PET/CT Imaging of Inflammatory Bowel Disease. Semin. Nucl. Med. 2013, 43, 420-426. [CrossRef]

149. Wang, H.; Machtaler, S.; Bettinger, T.; Lutz, A.M.; Luong, R.; Bussat, P.; Gambhir, S.S.; Tranquart, F.; Tian, L.; Willmann, J.K. Molecular Imaging of Inflammation in Inflammatory Bowel Disease with a Clinically Translatable Dual-Selectin-Targeted US Contrast Agent: Comparison with FDG PET/CT in a Mouse Model. Radiology 2013, 267, 818-829. [CrossRef]

150. Aarntzen, E.H.; Hermsen, R.; Drenth, J.P.; Boerman, O.C.; Oyen, W.J. 99mTc-CXCL8 SPECT to Monitor Disease Activity in Inflammatory Bowel Disease. J. Nucl. Med. 2016, 57, 398-403. [CrossRef] [PubMed]

151. Dmochowska, N.; Tieu, W.; Keller, M.D.; Wardill, H.R.; Mavrangelos, C.; Campaniello, M.A.; Takhar, P.; Hughes, P.A. ImmunoPET of Innate Immune Markers CD11b and IL-1beta Detects Inflammation in Murine Colitis. J. Nucl. Med. 2019, 60, 858-863. [CrossRef] [PubMed]

152. Freise, A.C.; Zettlitz, K.A.; Salazar, F.B.; Tavare, R.; Tsai, W.K.; Chatziioannou, A.F.; Rozengurt, N.; Braun, J.; Wu, A.M. ImmunoPET in Inflammatory Bowel Disease: Imaging CD4-Positive T Cells in a Murine Model of Colitis. J. Nucl. Med. 2018, 59, 980-985. [CrossRef]

153. Beziere, N.; Ntziachristos, V. Optoacoustic Imaging: An Emerging Modality for the Gastrointestinal Tract. Gastroenterology 2011, 141, 1979-1985. [CrossRef]

154. McNally, L.R.; Mezera, M.; Morgan, D.E.; Frederick, P.J.; Yang, E.S.; Eltoum, I.E.; Grizzle, W.E. Current and Emerging Clinical Applications of Multispectral Optoacoustic Tomography (MSOT) in Oncology. Clin. Cancer Res. 2016, 22, 3432-3439. [CrossRef]

155. Bhutiani, N.; Grizzle, W.E.; Galandiuk, S.; Otali, D.; Dryden, G.W.; Egilmez, N.K.; McNally, L.R. Noninvasive Imaging of Colitis Using Multispectral Optoacoustic Tomography. J. Nucl. Med. 2017, 58, 1009-1012. [CrossRef]

156. Dearling, J.L.; Park, E.J.; Dunning, P.; Baker, A.; Fahey, F.; Treves, S.T.; Soriano, S.G.; Shimaoka, M.; Packard, A.B.; Peer, D. Detection of Intestinal Inflammation by MicroPET Imaging Using a (64)Cu-Labeled Anti-beta(7) Integrin Antibody. Inflamm. Bowel Dis. 2010, 16, 1458-1466. [CrossRef]

157. Rath, T.; Bojarski, C.; Neurath, M.F.; Atreya, R. Molecular Imaging of Mucosal $\alpha 4 \beta 7$ Integrin Expression with the Fluorescent Anti-Adhesion Antibody Vedolizumab in Crohn's Disease. Gastrointest. Endosc. 2017, 86, 406-408. [CrossRef] [PubMed]

158. Turker, N.S.; Heidari, P.; Kucherlapati, R.; Kucherlapati, M.; Mahmood, U. An EGFR Targeted PET Imaging Probe for the Detection of Colonic Adenocarcinomas in the Setting of Colitis. Theranostics 2014, 4, 893-903. [CrossRef] [PubMed]

159. Coussens, L.M.; Werb, Z. Inflammation and Cancer. Nature 2002, 420, 860-867. [CrossRef] [PubMed]

160. Derlin, T.; Grünwald, V.; Steinbach, J.; Wester, H.-J.; Ross, T.L. Molecular Imaging in Oncology Using Positron Emission Tomography. Dtsch. Arztebl. Int. 2018, 115, 175-181. [CrossRef] [PubMed]

161. Motiei, M.; Dreifuss, T.; Betzer, O.; Panet, H.; Popovtzer, A.; Santana, J.; Abourbeh, G.; Mishani, E.; Popovtzer, R. Differentiating between Cancer and Inflammation: A Metabolic-Based Method for Functional Computed Tomography Imaging. ACS Nano 2016, 10, 3469-3477. [CrossRef]

162. Seyfer, P.; Pagenstecher, A.; Mandic, R.; Klose, K.-J.; Heverhagen, J.T. Cancer and Inflammation: Differentiation by USPIOEnhanced MR Imaging. J. Magn. Reson. Imaging 2014, 39, 665-672. [CrossRef]

163. Ntziachristos, V.; Razansky, D. Molecular Imaging by Means of Multispectral Optoacoustic Tomography (MSOT). Chem. Rev. 2010, 110, 2783-2794. [CrossRef]

164. Beziere, N.; Lozano, N.; Nunes, A.; Salichs, J.; Queiros, D.; Kostarelos, K.; Ntziachristos, V. Dynamic Imaging of PEGylated Indocyanine Green (ICG) Liposomes within the Tumor Microenvironment Using Multi-Spectral Optoacoustic Tomography (MSOT). Biomaterials 2015, 37, 415-424. [CrossRef]

165. Khanal, A.; Ullum, C.; Kimbrough, C.W.; Garbett, N.C.; Burlison, J.A.; McNally, M.W.; Chuong, P.; El-Baz, A.S.; Jasinski, J.B.; McNally, L.R. Tumor Targeted Mesoporous Silica-Coated Gold Nanorods Facilitate Detection of Pancreatic Tumors Using Multispectral Optoacoustic Tomography. Nano Res. 2015, 8, 3864-3877. [CrossRef]

166. Lee, S.J.; Nguyen, T.D.; Onstad, L.; Bar, M.; Krakow, E.F.; Salit, R.B.; Carpenter, P.A.; Rodrigues, M.; Hall, A.M.; Storer, B.E.; et al. Success of Immunosuppressive Treatments in Patients with Chronic Graft-Versus-Host Disease. Biol. Blood Marrow Transplant. 2018, 24, 555-562. [CrossRef] [PubMed]

167. McCracken, M.N.; Gschweng, E.H.; Nair-Gill, E.; McLaughlin, J.; Cooper, A.R.; Riedinger, M.; Cheng, D.; Nosala, C.; Kohn, D.B.; Witte, O.N. Long-Term In Vivo Monitoring of Mouse and Human Hematopoietic Stem Cell Engraftment with a Human Positron Emission Tomography Reporter Gene. Proc. Natl. Acad. Sci. USA 2013, 110, 1857-1862. [CrossRef]

168. Kao, R.L.; Truscott, L.C.; Chiou, T.T.; Tsai, W.; Wu, A.M.; De Oliveira, S.N. A Cetuximab-Mediated Suicide System in Chimeric Antigen Receptor-Modified Hematopoietic Stem Cells for Cancer Therapy. Hum. Gene Ther. 2019, 30, 413-428. [CrossRef] [PubMed]

169. Miletic, H.; Fischer, Y.; Litwak, S.; Giroglou, T.; Waerzeggers, Y.; Winkeler, A.; Li, H.; Himmelreich, U.; Lange, C.; Stenzel, W.; et al. Bystander Killing of Malignant Glioma by Bone Marrow-Derived Tumor-Infiltrating Progenitor Cells Expressing a Suicide gene. Mol. Ther. 2007, 15, 1373-1381. [CrossRef] [PubMed]

170. Federico Simonetta, I.S.A.; Lohmeyer, J.K.; Sahaf, B.; Good, Z.; Chen, W.; Xiao, Z.; Hirai, T.; Scheller, L.; Engels, P.; Vermesh, O.; et al. Molecular Imaging of Chimeric Antigen Receptor T Cells By ICOS-ImmunoPET. Clin. Cancer Res. 2020. [CrossRef] 
171. Sharon, H.; Elamvazuthi, I.; Lu, C.-K.; Parasuraman, S.; Natarajan, E. Development of Rheumatoid Arthritis Classification from Electronic Image Sensor Using Ensemble Method. Sensors 2019, 20, 167. [CrossRef] [PubMed]

172. Snekhalatha, U.; Anburajan, M.; Sowmiya, V.; Venkatraman, B.; Menaka, M. Automated Hand Thermal Image Segmentation and Feature Extraction in the Evaluation of Rheumatoid Arthritis. Proc. Inst. Mech. Eng. Part H J. Eng. Med. 2015, 229, 319-331. [CrossRef] [PubMed]

173. Tiulpin, A.; Thevenot, J.; Rahtu, E.; Lehenkari, P.; Saarakkala, S. Automatic Knee Osteoarthritis Diagnosis from Plain Radiographs: A Deep Learning-Based Approach. Sci. Rep. 2018, 8, 1727. [CrossRef] [PubMed]

174. Barraviera, B. The Journal of Venomous Animals and Toxins Including Tropical Diseases (JVATiTD) from 1995 to 2007. J. Venom. Anim. Toxins Incl. Trop. Dis. 2007, 13, 428-429. [CrossRef]

175. Ayalapogu, R.R.; Pabboju, S.; Ramisetty, R.R. Analysis of Dual Tree M-Band Wavelet Transform Based Features for Brain Image Classification. Magn. Reson. Med. 2018, 80, 2393-2401. [CrossRef] [PubMed]

176. Georgakopoulos, S.V.; Iakovidis, D.K.; Vasilakakis, M.; Plagianakos, V.; Koulaouzidis, A. Weakly-Supervised Convolutional Learning for Detection of Inflammatory Gastrointestinal Lesions. In Proceedings of the 2016 IEEE International Conference on Imaging Systems and Techniques (IST), Chania, Greece, 4-6 October 2016; pp. 510-514.

177. Sathiya, S.; Priyanka, G.; Jeyanthi, S. Detection of Chronic Obstructive Pulmonary Disease in Computer Aided Diagnosis System with CNN Classification. Int. J. Pure Appl. Math. 2018, 119, 13815-13821.

178. He, K.; Zhang, X.; Ren, S.; Sun, J. Deep Residual Learning for Image Recognition. In Proceedings of the 2016 IEEE Conference on Computer Vision and Pattern Recognition (CVPR), Las Vegas, NV, USA, 27-30 June 2016; pp. 770-778.

179. Simonyan, K.; Zisserman, A. Very Deep Convolutional Networks for Large-Scale Image Recognition. arXiv 2015, arXiv:1409.1556.

180. Szegedy, C.; Wei, L.; Yangqing, J.; Sermanet, P.; Reed, S.; Anguelov, D.; Erhan, D.; Vanhoucke, V.; Rabinovich, A. Going Deeper with Convolutions. In Proceedings of the 2015 IEEE Conference on Computer Vision and Pattern Recognition (CVPR), Boston, MA, USA, 7-12 June 2015; pp. 1-9.

181. Szegedy, C.; Ioffe, S.; Vanhoucke, V.; Alemi, A.A. Inception-v4, Inception-ResNet and the Impact of Residual Connections on Learning. In Proceedings of the Thirty-First AAAI Conference on Artificial Intelligence, San Francisco, CA, USA, 4-9 February 2017; pp. 4278-4284.

182. Zoph, B.; Vasudevan, V.; Shlens, J.; Le, Q.V. Learning Transferable Architectures for Scalable Image Recognition. In Proceedings of the 2018 IEEE/CVF Conference on Computer Vision and Pattern Recognition, Salt Lake City, UT, USA, 18-23 June 2018; pp. 8697-8710.

183. Möttönen, T.T. Prediction of Erosiveness and Rate of Development of New Erosions in Early Rheumatoid Arthritis. Ann. Rheum. Dis. 1988, 47, 648-653. [CrossRef]

184. Heijde, D. Joint Erosions and Patients with Early Rheumatoid Arthritis. Rheumatology 1995, 34, 74-78. [CrossRef]

185. Pauk, J.; Wasilewska, A.; Ihnatouski, M. Infrared Thermography Sensor for Disease Activity Detection in Rheumatoid Arthritis Patients. Sensors 2019, 19, 3444. [CrossRef]

186. Hirano, T.; Nishide, M.; Nonaka, N.; Seita, J.; Ebina, K.; Sakurada, K.; Kumanogoh, A. Development and Validation of a Deep-Learning Model for Scoring of Radiographic Finger Joint Destruction in Rheumatoid Arthritis. Rheumatol. Adv. Pract. 2019, 3, rkz047. [CrossRef]

187. Huang, Y.-J.; Shun, M.; Zheng, K.; Lu, L.; Lu, Y.; Lin, C.; Kuo, C.-F. Radiographic Bone Texture Analysis Using Deep Learning Models for Early Rheumatoid Arthritis Diagnosis. 2020. Available online: https://assets.researchsquare.com/files/rs-76193/v1 /6405299c-7383-4008-8420-e5082bba28fa.pdf (accessed on 23 October 2020).

188. Jiang, M.; Li, Y.; Jiang, C.; Zhao, L.; Zhang, X.; Lipsky, P.E. Machine Learning in Rheumatic Diseases. Clin. Rev. Allergy Immunol. 2020. [CrossRef]

189. Andersen, J.K.H.; Pedersen, J.S.; Laursen, M.S.; Holtz, K.; Grauslund, J.; Savarimuthu, T.R.; Just, S.A. Neural Networks for Automatic Scoring of Arthritis Disease Activity on Ultrasound Images. RMD Open 2019, 5, e000891. [CrossRef]

190. Humphries, S.M.; Centeno, J.P.; Notary, A.M.; Gerow, J.; Cicchetti, G.; Katial, R.K.; Beswick, D.M.; Ramakrishnan, V.R.; Alam, R.; Lynch, D.A. Volumetric Assessment of Paranasal Sinus Opacification on Computed Tomography Can Be Automated Using a Convolutional Neural Network. Int. Forum Allergy Rhinol. 2020, 10. [CrossRef]

191. Chowdhury, N.I.; Smith, T.L.; Chandra, R.K.; Turner, J.H. Automated Classification of Osteomeatal Complex Inflammation on Computed Tomography Using Convolutional Neural Networks. Int. Forum Allergy Rhinol. 2019, 9, 46-52. [CrossRef] [PubMed]

192. Sathiya, S.; Jeyanthi, S. Computer Aided Diagnosis System for Chronic Obstructive Pulmonary Disease from CT Images Using Convolutional Neural Network. In Proceedings of the International Conference on Intelligent Computing Systems (ICICS), Salem, India, 15-16 December 2017.

193. Bharati, S.; Podder, P.; Mondal, M.R.H. Hybrid Deep Learning for Detecting Lung Diseases from X-ray Images. Inform. Med. Unlocked 2020, 20, 100391. [CrossRef]

194. Heinemann, F.; Birk, G.; Schoenberger, T.; Stierstorfer, B. Deep Neural Network Based Histological Scoring of Lung Fibrosis and Inflammation in the Mouse Model System. PLoS ONE 2018, 13, e0202708. [CrossRef] [PubMed]

195. Wimmer, G.; Vécsei, A.; Uhl, A. CNN Transfer Learning for the Automated Diagnosis of Celiac Disease. In Proceedings of the 2016 Sixth International Conference on Image Processing Theory, Tools and Applications (IPTA), Oulu, Finland, 12-15 December 2016; pp. 1-6.

196. Gadermayr, M.; Wimmer, G.; Kogler, H.; Vécsei, A.; Merhof, D.; Uhl, A. Automated Classification of Celiac Disease during Upper Endoscopy: Status Quo and Quo Vadis. Comput. Biol. Med. 2018, 102, 221-226. [CrossRef] [PubMed]

197. Molder, A.; Balaban, D.V.; Jinga, M.; Molder, C.-C. Current Evidence on Computer-Aided Diagnosis of Celiac Disease: Systematic Review. Front. Pharmacol. 2020, 11, 341. [CrossRef] 
198. Srivastava, A.; Sengupta, S.; Kang, S.-J.; Kant, K.; Khan, M.; Ali, S.A.; Moore, S.R.; Amadi, B.C.; Kelly, P.; Syed, S. Deep Learning for Detecting Diseases in Gastrointestinal Biopsy Images. In Proceedings of the 2019 Systems and Information Engineering Design Symposium (SIEDS), Charlottesville, VA, USA, 26 April 2019; pp. 1-4.

199. Syed, S.; Stidham, R.W. Potential for Standardization and Automation for Pathology and Endoscopy in Inflammatory Bowel Disease. Inflamm. Bowel Dis. 2020, 26, 1490-1497. [CrossRef]

200. Ding, Z.; Shi, H.; Zhang, H.; Meng, L.; Fan, M.; Han, C.; Zhang, K.; Ming, F.; Xie, X.; Liu, H. Gastroenterologist-Level Identification of SmallBowel Diseases and Normal Variants by Capsule Endoscopy Using a Deep-Learning Model. Gastroenterology 2019, 157, 1044-1054.e1045. [CrossRef]

201. Zhu, R.; Niu, H.; Yin, N.; Wu, T.; Zhao, Y. Analysis of Varicose Veins of Lower Extremities Based on Vascular Endothelial Cell Inflammation Images and Multi-Scale Deep Learning. IEEE Access 2019, 7, 174345-174358. [CrossRef]

202. Sharifrazi, D.; Alizadehsani, R.; Joloudari, J.H.; Shamshirband, S.; Hussain, S.; Sani, Z.A.; Hasanzadeh, F.; Shoaibi, A.; Dehzangi, A.; Alinejad-Rokny, H. CNN-KCL: Automatic Myocarditis Diagnosis using Convolutional Neural Network Combined with K-means Clustering. Math. Comput. Sci. 2020. [CrossRef]

203. Leiner, T.; Rueckert, D.; Suinesiaputra, A.; Baeßler, B.; Nezafat, R.; Išgum, I.; Young, A.A. Machine Learning in Cardiovascular Magnetic Resonance: Basic Concepts and Applications. J. Cardiovasc. Magn. Reson. 2019, 21, 1-14. [CrossRef]

204. Kim, Y.; Lee, K.J.; Sunwoo, L.; Choi, D.; Nam, C.-M.; Cho, J.; Kim, J.; Bae, Y.J.; Yoo, R.-E.; Choi, B.S. Deep Learning in Diagnosis of Maxillary Sinusitis Using Conventional Radiography. Investig. Radiol. 2019, 54, 7-15. [CrossRef]

205. Heinemann, F.; Birk, G.; Stierstorfer, B. Deep Learning Enables Pathologist-Like Scoring of NASH Models. Sci. Rep. 2019, 9, 1-10. [CrossRef]

206. Joo, Y.B.; Baek, I.-W.; Park, Y.-J.; Park, K.-S.; Kim, K.-J. Machine Learning-Based Prediction of Radiographic Progression in Patients with Axial Spondyloarthritis. Clin. Rheumatol. 2020, 39, 983-991. [CrossRef]

207. Yang, Y.J.; Cho, B.-J.; Lee, M.-J.; Kim, J.H.; Lim, H.; Bang, C.S.; Jeong, H.M.; Hong, J.T.; Baik, G.H. Automated Classification of Colorectal Neoplasms in White-Light Colonoscopy Images via Deep Learning. J. Clin. Med. 2020, 9, 1593. [CrossRef] [PubMed]

208. Talo, M.; Baloglu, U.B.; Yıldırım, Ö.; Acharya, U.R. Application of Deep Transfer Learning for Automated Brain Abnormality Classification Using MR Images. Cogn. Syst. Res. 2019, 54, 176-188. [CrossRef]

209. Bayramoglu, N.; Heikkilä, J. Transfer Learning for Cell Nuclei Classification in Histopathology Images. In Proceedings of the European Conference on Computer Vision, Amsterdam, The Netherlands, 11-14 October 2016; pp. 532-539.

210. Ker, J.; Bai, Y.; Lee, H.Y.; Rao, J.; Wang, L. Automated Brain Histology Classification Using Machine Learning. J. Clin. Neurosci. 2019, 66, 239-245. [CrossRef] [PubMed]

211. Essa, E.; Aldesouky, D.; Hussein, S.E.; Rashad, M. Neuro-Fuzzy Patch-Wise R-CNN for Multiple Sclerosis Segmentation. Med. Biol. Eng. Comput. 2020, 58, 2161-2175. [CrossRef] [PubMed]

212. Birenbaum, A.; Greenspan, H. Multi-View Longitudinal CNN for Multiple Sclerosis Lesion Segmentation. Eng. Appl. Artif. Intell. 2017, 65, 111-118. [CrossRef]

213. Kaur, A.; Kaur, L.; Singh, A. State-of-the-Art Segmentation Techniques and Future Directions for Multiple Sclerosis Brain Lesions. Arch. Comput. Methods Eng. 2020, 1-27. [CrossRef]

214. Brooks, S.G.; Trope, M.; Blasetti, M.; Doghramji, L.; Parasher, A.; Glicksman, J.T.; Kennedy, D.W.; Thaler, E.R.; Cohen, N.A.; Palmer, J.N. Preoperative Lund-Mackay Computed Tomography Score Is Associated with Preoperative Symptom Severity and Predicts Quality-of-Life Outcome Trajectories after Sinus Surgery. Int. Forum Allergy Rhinol. 2018, 8, 668-675. [CrossRef] [PubMed]

215. Lund, V.J.; Mackay, I.S. Staging in Rhinosinusitis. Rhinology 1993, 31, 183. [CrossRef] 